\title{
How to Improve Worker-Firm Matching: Evidence from a Temporary Foreign Worker Market*
}

\author{
Yoonyoung $\mathrm{Cho}^{* *} \cdot$ Soohyung Lee***
}

This research investigates the role of worker-firm matching algorithms in accounting for early job separation rates. For this purpose, we examine Korea's temporary foreign worker program in which the government classifies firms by priority level and matches them with foreign workers on the basis of their stated preferences. Using administrative data, we examine predictors for the job separation rates and propose alternative matching methods using serial dictatorship. Our simulation results show that alternative matching methods can substantially reduce job separation rates, thereby suggesting a possible improvement of the Korean program.

JEL Classification: J4, J6, O15

Keywords: Job Matching, Temporary Immigrant, Migration, Market Design, Employment Permit System

\section{Introduction}

Globally, labor mobility is on a rising trend due in part to increases in migration for labor market opportunities. The International Labour Organization (ILO)

Received: June 18, 2020. Revised: Feb. 6, 2021. Accepted: April 30, 2021.

* We thank the Korea World Bank Partnership Facility and Korea Development Institute School of Public Policy for their generous funding for this research, and Korean Ministry of Employment and Labor for data sharing. We thank Ms. Seulgi Lim and Michell Dong for research assistance. We appreciate valuable comments from participants of various seminars and conferences including the Inter-American Development Bank (IADB) and the Asian \& Australian Society of Labour Economics (AASLE, Singapore). Lee acknowledges the supports by the IADB during her stay in spring 2019. The views expressed in this paper are entirely those of the authors; they do not necessarily represent the views of the International Bank for Reconstruction and Development/World Bank and its affiliated organizations or those of the Executive Directors of the World Bank or the governments they represent. All errors are our own.

** First Author, Senior Economist, Social Protection and Jobs Global Practice, World Bank, and IZA. 1818 H St. NW, Washington, DC 20433, E-mail: ychol@worldbank.org

*** Corresponding Author, Associate Professor, Graduate School of International Studies, Seoul National University; IZA and GLO. E-mail: soohlee@snu.ac.kr 
estimates that about 164 million migrant workers are active worldwide (ILO, 2017). Developed countries often rely on migrant workers to meet their labor needs, particularly for jobs that natives may not find attractive. In 2017, for instance, approximately 17 percent of the overall workforce in the United States were foreign born, and immigrants accounted for over 30 percent of workers involved in farming, construction, and the cleaning and maintenance of buildings (Bureau of Labor Statistics, 2018). The situation is similar in other developed countries. The overall share of migrant workers out of all workers in high-income countries is estimated to be around 18 percent, far higher than that in lower-income countries (2.2 and 1.4 percent among upper middle-income and lower middle-income countries, respectively) (ILO, 2017).

Given the importance of immigrants or migrant workers in the labor market, it is not surprising that numerous studies in economics have examined the direct and indirect impacts of immigration or flows of migrant workers on the labor market outcomes of native workers and the economies of host countries. For example, researchers have extensively examined the implications of migrant labor for native workers' earnings and employment (Borjas, 2014; Card and Peri, 2016, for overview), occupational choice (Cortés and Pan, 2015), women's labor supply (Cortés and Tessada, 2011), technology adoption (Lafortune, Tessada, and Conzales-Velosa, 2015), and trade and productivity (Ottaviano, Peri, and Wright, 2018). An equally substantial amount of research has been conducted on the implications for migrant workers' countries of origin with respect to, for example, human capital (Docquier and Rapoport, 2012), remittances (Clemens and McKenzie, 2018), and home production (Antman, 2012).

However, relatively little research has examined the degree of efficiency with which host countries utilize their migrant workforce. ${ }^{1}$ Furthermore, relative to permanent immigrants, temporary migrant workers have been understudied, mainly due to the poor quality of available data (Dustmann and Görlach, 2016). The current research aims to fill this gap in the literature by utilizing unusually rich datasets on temporary migrant workers in South Korea (hereafter referred to as "Korea"). Korea is an economically significant destination country in the international labor market. It attracts a large number of aspiring migrant workers from developing countries, particularly from Asia, and is regarded as a route to high-wage jobs overseas. ${ }^{2}$ According to the World Bank (2016), Korea is among the

\footnotetext{
${ }^{1}$ A particular type of migration, refugee resettlement, has recently been studied with the aim of improving efficiency. Using a simulation, Bansak et al. (2018) examine the extent to which an alternative algorithm could increase the employment rates of refugees compared with the status quo. Literature focused on market design has also examined refugee resettlement (e.g., Moraga and Rapoport, 2014; and Jones and Teytelboym, forthcoming; see a detailed summary in Kominers, Teytelboym, and Crawford, 2017).

${ }^{2}$ For example, Clemens and Tiongson (2017) report that the Korean temporary system enables
} 
top 10 countries from which migrant workers send the most remittances to the rest of the world. ${ }^{3}$

As in many other developed countries, the Korean government regulates the total number of migrant workers allowed in the country each year (by setting a quota), maintains a list of Korean firms that are allowed to hire foreigners in a given year, and follows up with migrant workers once they enter the country (as is done with holders of the $\mathrm{H} 2 \mathrm{~B}$ visa for temporary workers in the United States). Many developed countries have such systems in place, and other emerging countries (e.g., Thailand, Malaysia, and countries in the Middle East) are increasingly making efforts to manage their foreign workforce.

In addition to the similarity between the Korean system and those adopted by other countries, the Korean setting provides a unique advantage for researchers to examine migrant workforces. This advantage pertains to the fact that the labor market of temporary foreign workers is centralized and highly monitored by the Korean government. The government collects detailed information on firms and workers, what firms are matched with which workers, and the outcomes of the matches. Such information is rarely available to researchers because labor markets are decentralized in general; thus, no agency has an opportunity to collect such detailed information on a voluntary basis.

The Korean government directly manages the recruitment and screening of potential migrant workers as well as their matching to Korean firms through its Employment Permit System (EPS) introduced in 2004. Aspiring migrant workers apply directly for the EPS and take the Korean language test; only those who reach the minimum score are invited for a medical examination and potential job matching. Meanwhile, the EPS ranks applicant firms based on their eligibility criteria, which include the firm's size, performance, sector, and history of hiring foreign workers. The EPS gives priority to firms at the top of the list. It then invites representatives of the topmost firm on the list to a local job center to review the profiles of available candidates. A case worker at the job center narrows down a pool of pre-screened candidates according to the firm's stated preferences. The case worker then presents three candidate profiles for each position the firm is looking to fill. Once the firm identifies a candidate it wants, that candidate receives a job offer with an employment contract and is no longer available to other firms. The next firm on the list then visits the local job center and gets matched, and so on. In the process, the Korean government collects information on what types of workers the

workers to send sizable remittances to the Philippines, thus largely affecting spending, borrowing, and human capital investment in that country.

3 The top 10 remittance (in U.S. dollars) senders in 2014 included the United States (\$56.3 billion), Switzerland ( $\$ 24.7$ billion), Germany ( $\$ 20.8$ billion), France ( $\$ 13.8$ billion), Luxembourg ( $\$ 12.7$ billion), the United Kingdom ( $\$ 11.5$ billion), Italy ( $\$ 11.2$ billion), the Netherlands (\$9.9 billion), Korea ( $\$ 9.5$ billion), and Spain ( $\$ 8.8$ billion). 
firms searched for, the types of jobs the candidates requested, who is matched with whom, and the resulting outcomes.

This research examines early job separation rates, that is, the likelihood of a foreign temporary worker leaving their Korean employer within a year, as a main outcome variable of interest. Using the detailed administrative data, we empirically investigate the factors that may predict early job separation rates. Using those empirical results, we present alternative matching algorithms that may substantially reduce early job separation rates compared to the status quo algorithm in order for the Korean government to improve its matching process.

We focus on early job separation rates for two reasons: practical issues concerning policymakers in Korea and economic importance to firms and workers. From the perspectives of policymakers, an early job separation of a foreign worker draws additional resources from the Korean government because the latter assists in the job search of foreign workers. Some officials are also concerned that workers may drift away from the EPS and become illegal migrants. Administrative data show that more than a quarter of the employment contracts signed in 2013 and 2014 broke down in less than a year, even though the standard employment contract is three years. The concern that early job separation will generate illegal migrants is reasonable because foreigners who come to Korea under the EPS program can work only at another EPS participant firm, and if they do not find a job in three months, they lose their legal right to stay in Korea.

From an economic perspective, early job separation is costly to the Korean firms as they had spent time and resources to participate in the EPS and trained these workers on the job. These costs may be difficult to recoup if a labor contract is broken early. For the foreign workers who are already in Korea for work, early job separation may not be costly if they find better employment opportunities than their current jobs. However, ex-ante, it would be more efficient if the Korean government had helped those workers find employment with their ultimate employers instead of their initial employers. This is because the workers would not have spent time acquiring firm-specific human capital for their initial employers and would not have faced the risk of being unemployed during their job transition.

We examine an administrative dataset including the characteristics of workers and firms that were matched in 2013 and 2014 and their outcomes. Using regression analyses, we quantify to what extent those characteristics are associated with early job separation. Our results suggest that the current matching practices used at job centers may account for the high rate of early job separation. Typically, job centers first select a pool of candidates based on (i) the sector and wages preferred by workers and (ii) the firm's preference regarding the age, sex, and nationality of workers. However, we find that the characteristics considered in the selection process are not important predictors of early job separation. If firms and workers both want to avoid early job separation, then our findings imply that the current 
matching practices may generate a Pareto-inefficient equilibrium, suggesting the possibility of devising a better algorithm that yields lower job separation rates.

We examine the extent to which an alternative system generating Pareto efficiency may reduce early job separation. For this purpose, we use the serial dictatorship assignment to incorporate the fact that the Korean system explicitly favors high-priority firms by letting them choose workers first. Specifically, we sort firms on the basis of the priority assigned by the government and pick a firm from the list. For a given firm, we predict job separation rates for all available workers in our dataset, assign the worker with the lowest predicted job separation rate to the firm, and remove that worker from the candidate pools. We repeat this exercise until we exhaust all firms. Simulation results suggest that this alternative assignment process significantly reduces job separation rates compared with the status quo.

The alternative process reduces the job separation rate within one year and within two years by 10 percentage points (45 percent) and 12 percentage points (26 percent), respectively. The main reason for the predicted improvement relates to the fact that, in the alternative process, all possible candidates are reviewed for each firm, including those whose preferred sectors are not the same as the firm's sector. If we segregate the market by sectors and find the best match in a given sector, then the serial dictatorship algorithm reduces the within-one-year job separation rate by only 1.2 percentage points ( 5 percent) compared with the status quo.

This research contributes to the growing number of market design studies that empirically examine possible improvements in market efficiency. Many such studies examine the assignment of students to particular public schools in their vicinity. A smaller number of papers examine labor markets; because most such markets are decentralized, it is relatively difficult to devise policy instruments to correct inefficiencies. A few examples of labor market studies include Agarwal (2015), who studied the assignment of would-be doctors to hospital residency programs in the United States; Coles et al. (2010), who looked at the U.S. job market for recent recipients of a PhD in economics; and Niederle, Proctor, and Roth (2006), who considered the matching of medical students to gastroenterology fellowships in the United States. To the best of our knowledge, our study is the first to provide an empirical analysis of a migrant labor market in which market design approaches could lead to improved efficiency.

The rest of the paper is organized as follows. Section 2 presents a brief summary of the EPS's institutional background while Section 3 outlines the sources and descriptive statistics of our data. Section 4 documents worker-firm matching patterns and outcomes under the current system. Section 5 examines the possible outcomes under alternative worker-firm matching algorithms and the mechanisms through which alternative algorithms outperform the status quo. Section 6 presents robustness check results, and Section 7 concludes. 


\section{Institutional Background}

This section briefly explains the key features of the temporary foreign worker system in Korea. Further details on the system's history may be found in the National Archives of Korea (2006) and the system's evolution and detailed features in Cho et al. (2018).

\subsection{History of Temporary Labor Migration in Korea}

In May 1994, Korea established a temporary foreign worker system by inviting 20,000 individuals from developing countries to work in manufacturing. The jobs were restricted to those involving low-skilled manual labor for which firms had difficulty hiring natives. In the 10 years that this system was running, the number of foreign workers it attracted grew significantly and so did the associated problems. For example, a sizable number of foreign workers fled their original employment and/or extended their stay and became illegal immigrants.

In the initial system, firms relied on private intermediaries to find job candidates abroad. Likewise, job seekers from developing countries relied on brokers in their home countries to search for Korean firms. Brokers on both sides charged hefty fees, raising the cost of migration and incentivizing foreign workers to extend their stay in Korea illegally as they tried to recoup their costs. Moreover, the initial system allowed migrant workers to be hired as industrial trainees, which meant that they were not under labor regulations or social insurance applicable to workers. These left migrant workers vulnerable to exploitation, the risk of not being able to access medical service, and social isolation.

To address these concerns and improve the transparency of the system, the Korean government established the current system, called the EPS, in 2004. The EPS is based on bilateral agreements between the Korean government and the national governments of selected Asian countries. Beginning with just 6 countries originally, the EPS had expanded to 16 countries by $2015{ }^{4}$

\subsection{Overview of the Employment Permit System}

\section{Criteria for Participation}

Under the EPS, the Korean government tightly regulates the quota for temporary

\footnotetext{
${ }^{4}$ The Philippines, Thailand, Mongolia, Indonesia, Sri Lanka, and Vietnam were the original six countries. In 2006, Uzbekistan, Pakistan, and Cambodia joined, followed by China, Nepal, Bangladesh, Kyrgyzstan, and Myanmar in 2007, Timor-Leste in 2008, and Lao People's Democratic Republic in 2015.
} 
migrant workers and the eligibility of countries to participate. First, only those 16 countries with which the Korean government has formally established a bilateral agreement can participate. Second, the EPS offers temporary work visas that allow workers to stay in Korea for less than five years, prohibiting them from bringing their family members to Korea or converting the visa to permanent residency or naturalization. ${ }^{5}$ Third, applicants must demonstrate sufficient Korean language skills. In each of the 16 participating countries, the Korean government administers a language test called the Test of Proficiency in Korean (TOPIK) and selects the candidates whose test scores are higher than a predefined threshold. ${ }^{6}$ Among the workers who passed the test, a list of workers is compiled so that the number of applicants is three times as large as the total quota for each nationality and sector assigned by the Korean government. Fourth, only Korean firms in four sectors (manufacturing, agriculture, fisheries, and construction) that meet the predefined eligibility criteria can participate in the EPS.

\section{Process}

Figure 1 provides an overview of the EPS process. The Korean government compiles a roster of workers who passed the language test and medical checkups. The workers then fill out application forms asking for information on their characteristics (age, height, weight, marital status, education) and job preferences (choice of sector, industry, and location). Upon their successful completion of these steps, each worker remains on the roster for a year.

Korean firms that have difficulty hiring native workers and meet other eligibility criteria may participate in the EPS. ${ }^{7}$ The Korean government assigns a score to each participating firm based on the government's policy target and the firm's characteristics, which may vary by year. ${ }^{8}$ For example, if the Korean government decides to prioritize the agricultural and fisheries sectors over the manufacturing and construction sectors for a given year, then firms in the agricultural and fisheries

\footnotetext{
${ }^{5}$ These features are comparable to the U.S. temporary guest worker permit (H2B). However, the EPS is different from the U.S. permit in that it targets non-seasonal jobs while the H2B targets seasonal jobs.

${ }^{6}$ The objective of the test, which consists of reading and listening sections, is to screen workers to ensure that they understand basic work instructions, safety signs, and basic information needed to function well in Korea. The test is graded on a point system with a maximum of 200 points. Only those who achieve a minimum score of 80 can proceed to the subsequent steps of the EPS.

7 The eligibility of firms is evaluated on the basis of the sector (manufacturing, agriculture, fishery, and construction), their efforts to hire Korean workers (e.g., job advertisement for 14 days and interviews with potential candidates), the percentage of foreign workers in their workforce, the working conditions, and the facilities (e.g., dormitories). Firms should have no prior record of worker abuse. Firms receive a score based on these eligibility criteria, and those that rank above a certain threshold are allowed to be a part of the EPS pool.

${ }^{8}$ The quantitative formula for calculating priority scores is not publicly available.
} 
sectors will have higher scores on average than do their counterparts in the two other sectors. A firm's characteristics include information on the sector, whether it has ever hired any foreign guest workers and, if so, whether it has been known to delay a worker's compensation. However, the score does not depend on whether the firm has experienced early job separation with its previous foreign workers.

[Figure 1] EPS Process at a Glance

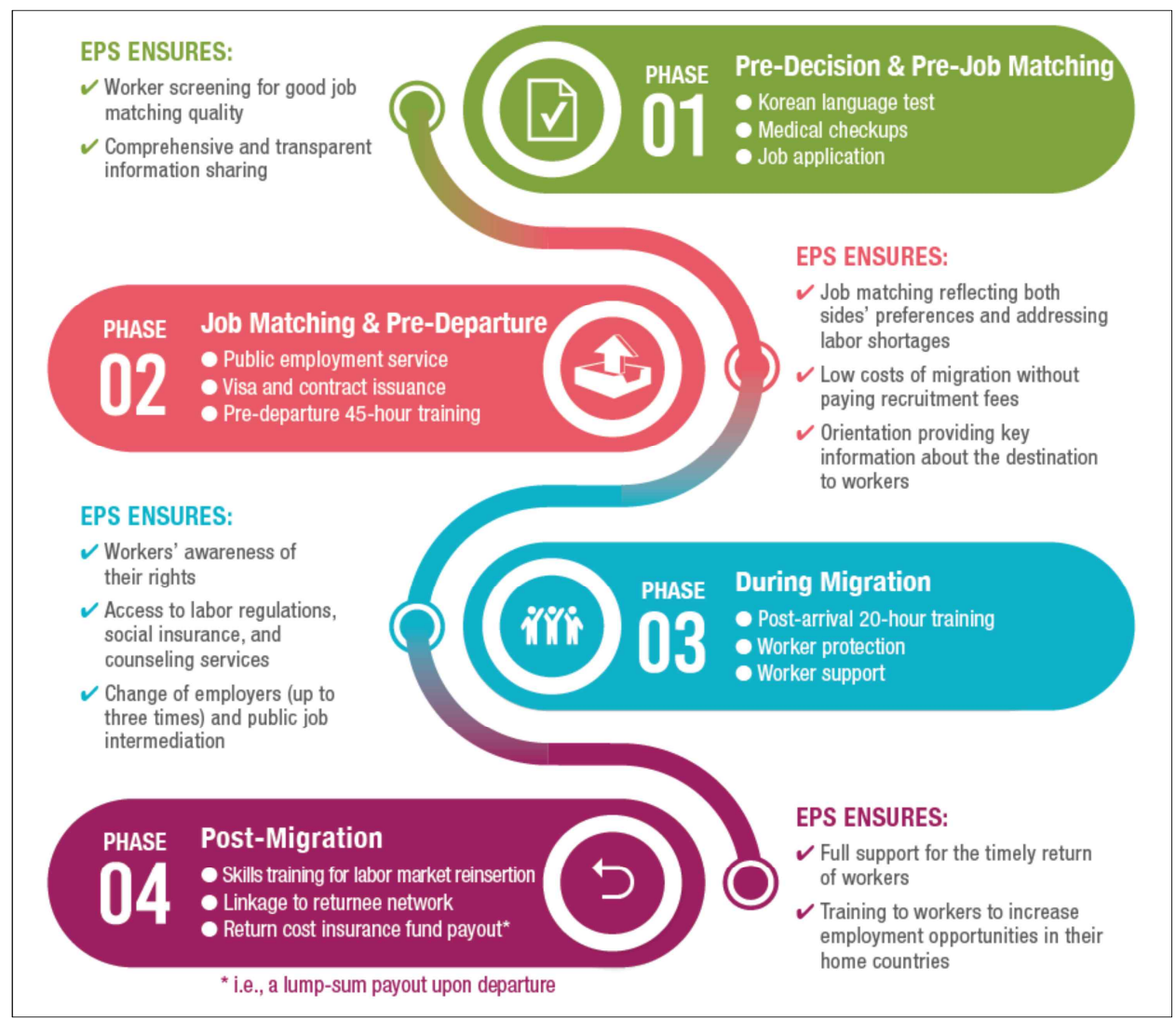

Source: Cho et al. (2018).

Once scores are assigned to all firms, the Korean government sorts firms in descending order and in sequence invites a representative from whichever firm is at the top of the list to choose workers from a pool of available candidates. Given that the Korean government uses the scores to prioritize firms, we refer to the scores as "priority scores" throughout this manuscript. The subsequent subsection, 2.3, will describe the details of this matching process, which is the key focus of this research.

Upon a worker's agreement to be hired, the Korean government provides the worker with a labor contract, pre-departure training, and support in the visa application process. Once the worker arrives in Korea, the Korean government 
provides orientation and training sessions as well as the contact information of job centers that provide additional services, such as training and counseling. If the employment contract does not work out (either due to the decision of the worker or the firm), a job center helps the worker find another job with an EPS-eligible firm within three months. If a worker does not have any employment contract after three months, then they will need to return to their home country.

After working in Korea for the time period allowed in the contract, foreign guest workers should return to their home countries. The EPS has several measures to incentivize the return. First, workers who leave on time are returned the money that they, upon migrating, paid for the repatriation insurance. Second, workers who stayed with one firm for 58 months and returned home on time are offered an option to come back to Korea for work after spending a minimum of three months in their home countries. Finally, the government provides pre-departure training of language and vocation for up to six months to workers who declare their intention to return home. The training is meant to help the workers build their own businesses back home by utilizing their work experience in Korea.

\subsection{Job-matching Procedure}

Job centers are located across Korea as part of the country's public employment service to help firms find workers and support EPS firms and migrant workers. Each job center invites a representative of the firms according to their rank order on the EPS list of firms. When the firm's representative visits the job center, a case worker presents a short list of job candidates from the EPS pool and checks whether the firm wants to hire any of the candidates. The process is as follows.

To retrieve the information on job candidates for a firm, a case worker needs to specify five criteria: sector, wage, sex, age, and nationality. By inputting the sector of the firm and the proposed monthly wage, the interface retrieves a set of candidates who prefer to work in the same sector and desire the level of wages the firm can provide (up to 1.1 million won, 1.1-1.5 million won, and above 1.5 million won). The case worker then further narrows the pool to meet the firm's reported preference for age group (18-26 years, 27-36 years, 37 years and above), gender, and nationality.

Second, once a set of candidates is retrieved from the database, the case worker sorts the list based on the firm's preferences for characteristics, such as marital status, language skills, and age (a specific age, not an age group). The relative importance given to each characteristic is left to the discretion of the case worker. From the top of the resulting list, the case worker presents the profiles of three candidates per job to the firm.

Third, the firm representative can review the three profiles for up to 90 minutes before it makes its decision. Alternatively, the firm can request another set of three 
candidates by changing or refining its preferences (as reported in the second step) in order to find a better candidate. Once the firm finds a suitable candidate, the case worker removes the candidate from the EPS pool so that they are no longer available to other firms.

A few features are worth highlighting because they could lead to early job separation. First, neither case workers nor firms review candidates outside of the characteristics used in the first and second steps. This sequential selection also removes the candidate once a firm finds them suitable without allowing the candidate to review the characteristics of potential employers or providing other firms opportunities to compete for the same candidate. Thus, if the characteristics used in the selection are not the main determinants of job-matching success (or separation) rates, then selection based solely on those characteristics likely yields inefficient matching.

Additionally, not all firm representatives manage to visit a job center during the time slot allocated to them, especially during their peak work seasons. As a result, despite the intentions of the Korean government, the firms assigned a high priority may not necessarily benefit from the system.

Finally, creating a shortlist of candidates for each firm depends critically on a few stated preferences that may not accurately reflect the true preferences of firms and workers. For example, the EPS asks job candidates about their preferred sectors and only offers a job (if any) in a preferred sector. Anecdotal evidence suggests that foreign workers tend to have only limited information about the jobs available via the EPS. Many of the workers have no strong preferences for a particular sector; rather, they try to choose a sector that they think could increase their chances of getting a job offer. Relatedly, the firms eligible for the EPS are small in size, and most hire only a small number of foreign workers. Thus, these firms may not have sufficient information to accurately identify preferable characteristics in terms of gender, nationality, and age.

Note that worker-firm matching in the current process may not be Pareto efficient because the process allows firms and workers to observe only a few candidates out of all available participants when making their decisions. If this is so, then we can devise an alternative algorithm generating Pareto-efficient outcomes and examine the possibility that the alternative algorithm may yield lower job separation rates than the status quo process.

\section{Data and Summary Statistics}

\subsection{Data Sources and Sample}

We use information on workers and firms that were matched through the EPS at 
least once between January 2013 and December 2014. Among them, we limit our sample to the job candidates who were hired for the first time by a Korean employer during this period. This gives us 111,355 worker-firm matching cases. If a firm hires two or more workers from the EPS at the same time, then one match per firm is selected randomly. This selection is done to create a sample that represents the average of Korean firms eligible for the EPS instead of a weighted sample of firms by the number of hires. This criterion removes 33,322 matches. Lastly, we narrow our sample to those matches for which we have all key information that the EPS makes available to market participants when they decide to accept or reject a job match (e.g., worker's age, nationality, and education; firm's wage, sector/industry, and location). As a result, our final sample consists of 73,930 worker-firm matches.

The data cover the characteristics and preferences of workers and firms. The EPS records the date when the job match was signed - and dissolved, if applicable, and the reasons for the dissolution. For among those who separated from their initial match, we examine the workers' subsequent job search and matching in Korea.

\subsection{Summary Statistics}

\subsubsection{Workers}

Table 1 summarizes our statistics on workers who were employed by Korean firms through the EPS and migrated to Korea between 2013 and 2014. Only 8 percent are women, and the average age is 28 . Five countries, namely, Indonesia, Cambodia, the Philippines, Vietnam, and Nepal, account for 57 percent of the workers. The EPS classifies candidates into three groups depending on their proficiency in the Korean language: mediocre, good, and excellent. Over 80 percent of workers in the sample belong to the middle group while 9.4 percent belong to the top group.

As for schooling, the majority of workers in the sample are high school graduates (56 percent) while 21 percent are middle school graduates. Most of the workers have not taken an EPS-administered optional skill test (81 percent). Those who did take the skill test are classified into three equally sized groups according to the level of their performance (bottom, middle, and top), with each accounting for approximately 6 percent.

In our sample, 76 percent of workers chose manufacturing as their preferred sector while 11 percent chose agriculture. Regarding location, 69 percent of workers stated that they had no preference. 
[Table 1] Composition of Workers

\begin{tabular}{|c|c|c|c|c|}
\hline & $\begin{array}{c}\text { Average } \\
\text { (1) }\end{array}$ & $\begin{array}{l}\text { S.D. } \\
\text { (2) }\end{array}$ & $\begin{array}{l}\text { Min } \\
(3)\end{array}$ & $\begin{array}{c}\operatorname{Max} \\
(4)\end{array}$ \\
\hline \multicolumn{5}{|l|}{ Panel A. Characteristics } \\
\hline 1 if female & 0.080 & 0.271 & 0 & 1 \\
\hline Age & 28.237 & 5.288 & 18 & 52 \\
\hline \multicolumn{5}{|l|}{ Nationality } \\
\hline - Indonesia & 0.163 & 0.369 & 0 & 1 \\
\hline - Cambodia & 0.131 & 0.338 & 0 & 1 \\
\hline - Vietnam & 0.089 & 0.284 & 0 & 1 \\
\hline - Nepal & 0.089 & 0.285 & 0 & 1 \\
\hline - Philippines & 0.102 & 0.302 & 0 & 1 \\
\hline - Sri Lanka & 0.085 & 0.279 & 0 & 1 \\
\hline - Myanmar & 0.069 & 0.254 & 0 & 1 \\
\hline - Thailand & 0.108 & 0.310 & 0 & 1 \\
\hline - Rest & 0.164 & 0.370 & 0 & 1 \\
\hline \multicolumn{5}{|l|}{ Language proficiency } \\
\hline - Mediocre & 0.121 & 0.326 & 0 & 1 \\
\hline - Good & 0.803 & 0.398 & 0 & 1 \\
\hline - Excellent & 0.076 & 0.265 & 0 & 1 \\
\hline \multicolumn{5}{|l|}{ Education } \\
\hline - Less than middle school & 0.130 & 0.336 & 0 & 1 \\
\hline - Middle school & 0.214 & 0.410 & 0 & 1 \\
\hline - High school & 0.557 & 0.497 & 0 & 1 \\
\hline - College & 0.099 & 0.299 & 0 & 1 \\
\hline \multicolumn{5}{|l|}{ Skill } \\
\hline - Not taken & 0.812 & 0.390 & 0 & 1 \\
\hline - Bottom & 0.058 & 0.233 & 0 & 1 \\
\hline - Middle & 0.067 & 0.249 & 0 & 1 \\
\hline - Top & 0.064 & 0.244 & 0 & 1 \\
\hline \multicolumn{5}{|l|}{ Panel B. Preferences } \\
\hline \multicolumn{5}{|l|}{ Desired sector } \\
\hline - Manufacturing & 0.757 & 0.429 & 0 & 1 \\
\hline - Construction & 0.084 & 0.277 & 0 & 1 \\
\hline - Agriculture & 0.106 & 0.308 & 0 & 1 \\
\hline - Service & 0.000 & 0.020 & 0 & 1 \\
\hline - Fisheries & 0.053 & 0.224 & 0 & 1 \\
\hline 1 if no desired location & 0.685 & 0.465 & 0 & 1 \\
\hline
\end{tabular}

Note: The sample consists of workers who found a job between January 2013 and December 2014 (73,930 workers).

\subsubsection{Firms}

Table 2 presents the summary statistics of the job postings in our sample: 73,930 job postings filled during the sample period, posted by 37,169 firms (2 postings per firm on average). Manufacturing sector jobs account for 78 percent while the 
agricultural sector accounts for 11 percent. A total 70 percent of jobs provide all of the four types of insurance available through EPS, namely, employment insurance, workers' compensation, the national pension scheme, and national health insurance, while only 44 percent of the jobs are mandated to do so.

As discussed in Section 2, the EPS assigns priority scores to firms and uses the scores in its worker-firm matching process. Unfortunately, our dataset does not have the priority scores of all firms, only 29 percent of them. Given our limited priority score information and in order to use firms without priority scores in our analyses, we create a categorical variable related to priority scores by classifying jobs into four groups: without priority scores (71 percent), low scores (10 percent), middle scores (13 percent), and high scores (7 percent).

[Table 2] Composition of Job Postings

\begin{tabular}{|c|c|c|c|c|c|}
\hline $\begin{array}{l}\text { Sectors } \\
\text { [share] }\end{array}$ & $\begin{array}{c}\text { All } \\
{[100 \%]} \\
(1)\end{array}$ & $\begin{array}{c}\text { Manuf. } \\
{[78.2 \%]} \\
(2)\end{array}$ & $\begin{array}{c}\text { Constr. } \\
{[5.9 \%]} \\
(3)\end{array}$ & $\begin{array}{c}\text { Agri. } \\
{[10.6 \%]} \\
(4)\end{array}$ & $\begin{array}{c}\text { Fish. } \\
{[5.3 \%]} \\
(5)\end{array}$ \\
\hline \multicolumn{6}{|l|}{ Panel A. Characteristics } \\
\hline 1 if providing all four insurances & 0.700 & 0.834 & 0.727 & 0.040 & 0.016 \\
\hline \multicolumn{6}{|l|}{ Priority scores } \\
\hline - NA & 0.711 & 0.699 & 0.775 & 0.747 & 0.749 \\
\hline - Low & 0.097 & 0.117 & 0.072 & 0.005 & 0.003 \\
\hline - Middle & 0.125 & 0.139 & 0.116 & 0.079 & 0.027 \\
\hline - High & 0.066 & 0.044 & 0.037 & 0.169 & 0.220 \\
\hline \multicolumn{6}{|l|}{ No. of Korean workers } \\
\hline - Less than 5 & 0.438 & 0.325 & 0.461 & 0.976 & 0.995 \\
\hline - Between 5 and 9 & 0.142 & 0.173 & 0.080 & 0.015 & 0.004 \\
\hline - Between 10 and 49 & 0.336 & 0.403 & 0.331 & 0.009 & 0.001 \\
\hline - More than 49 & 0.085 & 0.099 & 0.128 & 0.001 & 0.000 \\
\hline \multicolumn{6}{|l|}{ No. of foreign guest workers } \\
\hline - None & 0.072 & 0.030 & 0.029 & 0.219 & 0.437 \\
\hline - Between 1 and 4 & 0.403 & 0.367 & 0.280 & 0.659 & 0.558 \\
\hline - Between 5 and 9 & 0.321 & 0.377 & 0.271 & 0.098 & 0.005 \\
\hline - More than 9 & 0.204 & 0.226 & 0.420 & 0.023 & 0.000 \\
\hline $\begin{array}{l}\text { Real monthly wages } \\
\text { (10,000 won) }\end{array}$ & 111.006 & 109.560 & 109.697 & 118.179 & 119.372 \\
\hline - Category 1 (below 104.0) & 0.349 & 0.414 & 0.373 & 0.024 & 0.018 \\
\hline - Category $2(104.0-109.7)$ & 0.300 & 0.347 & 0.378 & 0.048 & 0.020 \\
\hline - Category 3 (109.7-116.7) & 0.141 & 0.104 & 0.105 & 0.334 & 0.342 \\
\hline - Category 4 (116.7-124.8) & 0.149 & 0.086 & 0.099 & 0.471 & 0.496 \\
\hline - Category 5 (124.8 and over] & 0.061 & 0.050 & 0.045 & 0.124 & 0.124 \\
\hline \multicolumn{6}{|l|}{ Location } \\
\hline - Seoul & 0.006 & 0.007 & 0.008 & 0.003 & 0.000 \\
\hline - Busan & 0.027 & 0.032 & 0.025 & 0.007 & 0.003 \\
\hline - Daegu & 0.019 & 0.024 & 0.003 & 0.000 & 0.000 \\
\hline - Incheon & 0.055 & 0.066 & 0.021 & 0.008 & 0.034 \\
\hline
\end{tabular}


[Table 2] Composition of Job Postings (continued)

\begin{tabular}{lccccc}
\hline $\begin{array}{l}\text { Sectors } \\
\text { [share] }\end{array}$ & $\begin{array}{c}\text { All } \\
{[100 \%]}\end{array}$ & $\begin{array}{c}\text { Manuf. } \\
{[78.2 \%]}\end{array}$ & $\begin{array}{c}\text { Constr. } \\
{[5.9 \%]}\end{array}$ & $\begin{array}{c}\text { Agri. } \\
{[10.6 \%]}\end{array}$ & $\begin{array}{c}\text { Fish. } \\
{[5.3 \%]}\end{array}$ \\
& $(1)$ & $(2)$ & $(3)$ & $(4)$ & $(5)$ \\
\hline $\begin{array}{l}\text { Location } \\
\quad \text { Gwangju }\end{array}$ & 0.015 & 0.017 & 0.007 & 0.012 & 0.000 \\
$\quad$ - Daejeon & 0.003 & 0.004 & 0.006 & 0.001 & 0.000 \\
$\quad$ - Ulsan & 0.016 & 0.018 & 0.008 & 0.006 & 0.011 \\
$\quad$ - Sejong & 0.004 & 0.004 & 0.007 & 0.003 & 0.000 \\
$\quad$ - Gyeonggi-do (omitted) & 0.379 & 0.417 & 0.236 & 0.363 & 0.010 \\
$\quad$ - Gangwon-do & 0.018 & 0.006 & 0.028 & 0.097 & 0.034 \\
$\quad$ - Chungcheongbuk-do & 0.039 & 0.042 & 0.072 & 0.022 & 0.000 \\
$\quad$ - Chungcheongnam-do & 0.057 & 0.047 & 0.057 & 0.112 & 0.097 \\
$\quad$ - Jeonlabuk-do & 0.035 & 0.026 & 0.040 & 0.068 & 0.095 \\
$\quad$ - Jeollanam-do & 0.042 & 0.027 & 0.036 & 0.068 & 0.222 \\
$\quad$ - Gyeongsangbuk-do & 0.058 & 0.063 & 0.040 & 0.028 & 0.071 \\
$\quad$ - Gyeongsangnam-do & 0.108 & 0.113 & 0.064 & 0.061 & 0.175 \\
$\quad$ - Jeju-do & 0.014 & 0.004 & 0.022 & 0.040 & 0.103 \\
$\quad$ - Missing & 0.104 & 0.085 & 0.321 & 0.102 & 0.144 \\
Panel B. Preferences & & & & & \\
1 if no preferred sex & 0.700 & 0.674 & 0.787 & 0.785 & 0.819 \\
1 if no preferred nationality & 0.692 & 0.666 & 0.772 & 0.781 & 0.811 \\
1 if no preferred age & 0.675 & 0.655 & 0.761 & 0.741 & 0.744 \\
1 if no preferred language skills & 0.996 & 0.995 & 0.995 & 0.998 & 0.998 \\
\hline Not The sampl consists & & & & & \\
\hline
\end{tabular}

Note: The sample consists of firms that filled their job postings between January 2013 and December 2014 (73,930 jobs).

Approximately 44 percent of jobs are posted by firms that hire fewer than five Korean workers, and most of the firms involved already have at least one foreign guest worker (93 percent). Over 44 percent of jobs are located in Seoul and its surroundings (i.e., Incheon and Gyeonggi-do).

Most jobs in our sample pay workers the minimum wage. The average monthly wage is 1.1 million Korean won, approximately $\$ 1,100$, which is around the minimum wage for full-time work (around 40 hours a week). As shown in Figure 2, there is bunching around 1.04 million won (30 percent) and 1.096 million won (26 percent). Jobs paying more than 1.26 million won are relatively few (6 percent). Thus, jobs are classified into five groups depending on how much they pay. The bottom category includes jobs paying less than 1.04 million won (35 percent) while the second lowest category covers jobs paying between 1.040 and 1.097 million won (containing 30 percent). The third category covers jobs paying between 1.097 and 1.167 million won (14 percent) while the fourth category includes jobs paying between 1.097 and 1.167 million won (15 percent). The fifth category (and the highest paying category) covers the rest (6 percent). The corresponding average monthly wages in each wage category are 1.030, 1.092, 1.120, 1.195, and 1.422 
million won, respectively.

The majority of employers did not express preferences for certain worker characteristics at the time of posting their job opening. Almost none asked for Korean language skills, and very few specified a preferred sex (30 percent), nationality (31 percent), or age group (32 percent). They tend to further specify their preference when they come to job centers for the selection of workers.

[Figure 2] Distribution of Monthly Wages

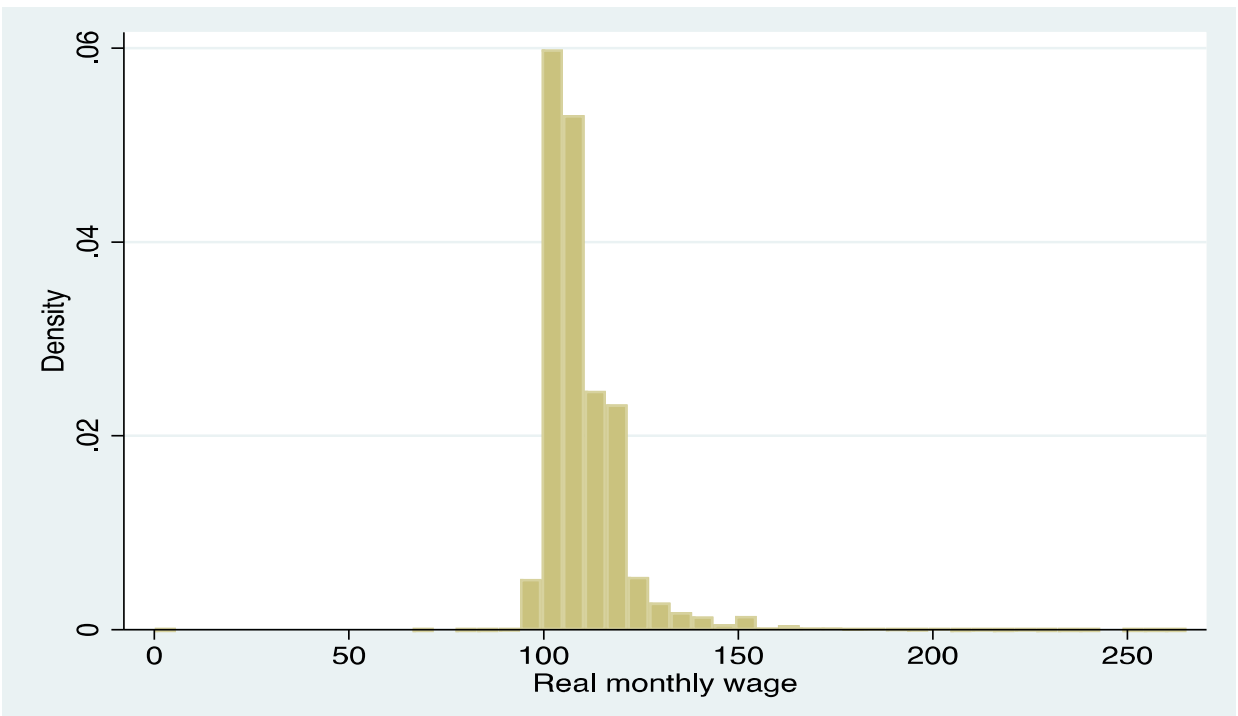

Note: The unit of monthly wage shows in the figure is 10,000 Korean won (W) in 2015 real terms.

\section{Status Quo}

\subsection{Preferences and Matching Patterns of Firms and Workers}

We now more closely examine the typical process followed by job center case workers and how matching reflects the expressed preferences of the firms and workers. To do this, we compare the actual matching patterns with the simulated patterns based on random matchings between firms and workers in our dataset. The sorting patterns between the actual and simulated matches can be different for two reasons. One is due to the job center's screening of candidates. That is, a firm needs to choose its match from among the candidates that the job center selects for the firm in a nonrandom manner. The other is the firm's preferences for certain characteristics among the suggested candidates. Thus, the difference in sorting 
patterns between the actual and random matches partially reflects the methods employed by job centers.

To generate random matching, we separate job postings and candidates by month in a year, randomly pair them without considering any preferences or characteristics, and calculate the sorting pattern by each sector. To reduce

[Table 3] Firm-Worker Matching Patterns

\begin{tabular}{|c|c|c|c|c|c|}
\hline Types & Actual & Predicted & Predicted & Predicted & Predicted \\
\hline Matching & $\begin{array}{c}\text { Status } \\
\text { quo } \\
(1) \\
\end{array}$ & Random & $\begin{array}{c}\text { Serial } \\
\text { Dictatorship } \\
\text { Cross } \\
\text { Sector } \\
(3) \\
\end{array}$ & $\begin{array}{c}\text { Serial } \\
\text { Dictatorship } \\
\text { Within } \\
\text { Sector } \\
(4) \\
\end{array}$ & $\begin{array}{l}2 \text { year: } \\
\text { Cross } \\
\text { Sector } \\
(5)\end{array}$ \\
\hline \multicolumn{6}{|l|}{ A. Sectors ( 5 categories) } \\
\hline$-\mathrm{F}$ : sector $=\mathrm{W}$ : pref. & 91.96 & 62.97 & 62.17 & 95.42 & 58.89 \\
\hline -not respected & 8.04 & 37.03 & 37.83 & 4.58 & 41.11 \\
\hline \multicolumn{6}{|l|}{ B. Industry (40 among firms) } \\
\hline$-\mathrm{F}:$ industry $=\mathrm{W}$ : pref. & 30.19 & 5.31 & 30.17 & 45.95 & 29.99 \\
\hline -not respected & 69.81 & 94.69 & 69.83 & 54.05 & 70.01 \\
\hline \multicolumn{6}{|l|}{ C. Nationality } \\
\hline -F: no preference & 69.17 & 69.19 & 69.18 & 69.18 & 69.19 \\
\hline$-F^{\prime}$ s 1 st pref $=W$ : nationality & 10.43 & 2.22 & 1.32 & 2.15 & 0.66 \\
\hline -F's 2nd pref $=W$ : nationality & 9.11 & 1.76 & 4.50 & 5.65 & 4.64 \\
\hline- not respected & 11.28 & 26.84 & 25.00 & 23.03 & 25.51 \\
\hline \multicolumn{6}{|l|}{ D. Location } \\
\hline -W: no preference & 68.47 & 68.47 & 68.47 & 68.47 & 68.47 \\
\hline$-\mathrm{W}$ : pref location $=\mathrm{F}$ : location & 8.09 & 3.25 & 18.04 & 17.18 & 19.51 \\
\hline -not respected & 23.44 & 28.28 & 13.49 & 14.34 & 12.02 \\
\hline \multicolumn{6}{|l|}{ E. Sex } \\
\hline -F: no preference & 69.99 & 69.99 & 69.99 & 69.99 & 69.99 \\
\hline -F: pref sex $=W$ : sex & 29.20 & 26.13 & 22.02 & 23.45 & 22.74 \\
\hline -not respected & 0.81 & 3.88 & 7.99 & 6.56 & 7.27 \\
\hline \multicolumn{6}{|l|}{ F. Age } \\
\hline $\begin{array}{l}\text {-F: pref age rangelinc. W: age, } \\
\text { * including no pref. }\end{array}$ & 94.67 & 92.60 & 83.88 & 83.75 & 82.91 \\
\hline -not respected & 5.33 & 7.40 & 16.12 & 16.25 & 17.09 \\
\hline \multicolumn{6}{|l|}{ G. Korean language skill } \\
\hline - F: no preference & 99.56 & 99.56 & 99.56 & 99.56 & 99.56 \\
\hline $\begin{array}{l}\text { - F: good = W: good or } \\
\text { excellent }\end{array}$ & 0.41 & 0.39 & 0.42 & 0.43 & 0.41 \\
\hline - F: good $=\mathrm{W}$ : mediocre & 0.03 & 0.05 & 0.02 & 0.01 & 0.03 \\
\hline
\end{tabular}

Notes: The sample consists of 72,087 job postings and the same number of workers who found a job between January and December 2014. The capital letters "F" and "W" stand for firms and workers, respectively. Column 1 reports the matching patterns shown in the matched job postings while column 2 is calculated from random counterfactual matchings between firms and workers. 
simulation errors, we conduct the random matching 100 times and take the average of the results.

Columns 1 and 2 of Table 3 show the actual and random matching patterns between firms and workers. In the large majority of cases (92 percent), workers found jobs in their preferred sectors; only 8 percent of workers were matched with firms in sectors different from their preferred ones (panel A). By comparison, when job candidates and firms were paired randomly, only 63 percent of workers were matched with their preferred sectors (column 2, panel A). Next, we examine the sorting pattern by subsector-or industry-because the EPS asks job candidates about their industry preferences as well. We classify jobs into 40 industries across the four sectors covered by the EPS. As shown in panel B, 30 percent of workers found a job matching their industry preference according to the data used for this study while that share decreases to 5 percent in the random matching case.

With respect to nationality (panel C), approximately 10 percent of firms hired workers whose nationality matched their top preference. Another 9 percent of firms hired workers of nationalities they ranked second while 11 percent of firms had stated preferred nationalities but did not hire workers that matched those. Among random matches, 27 percent of firms were not able to hire workers according to their nationality preferences.

For the rest of the characteristics (panels D through $G$ ), smaller differences in sorting patterns are found between actual and random matches. Nonetheless, actual matches meet the preference slightly better than do random matches in terms of location, sex, age, and language skills of workers.

\subsection{Matching Outcomes}

The outcome of interest is the job separation rate within a year since matching. We choose one year as the cutoff because it captures an early job separation compared to three years, which is the length of EPS contract for first-time foreign workers.

Several factors motivate us to examine this outcome variable. Within-one-year job separation is the outcome of interest among policy makers in the Ministry of Employment and Labor (MOEL) and other ministries; this was made clear during our interviews with several government officials. In addition, early job separation requires additional resources for the Korean government to assist in the job search for foreign workers. Some officials are also concerned that the workers may drift away from the EPS and become illegal immigrants. Another factor is the cost for firms, who spend time and money to participate in the system, pay costs to host workers in Korea, and train the workers. These costs are difficult to recoup within a year of employment. Korean regulations consider one year as the minimum length of employment for a worker to claim their contribution from their employers and be 
entitled to severance pay. ${ }^{9}$ Finally, there is an opportunity cost for workers. Just like firms, the workers need to invest in firm-specific human capital and, without a reasonable length of employment, the investment may not be profitable. ${ }^{10}$ Certainly,

[Table 4] Probability of Job Separation Within a Year

\begin{tabular}{|c|c|c|c|c|c|}
\hline Types & Actual & Baseline & Baseline & Cross sector & Within sector \\
\hline Matching & $\begin{array}{l}\text { Status } \\
\text { quo } \\
(1)\end{array}$ & $\begin{array}{c}\text { Linear } \\
\text { regression } \\
\text { (Predicted) } \\
(2)\end{array}$ & $\begin{array}{c}\text { Random } \\
\text { (predicted) } \\
(3) \\
\end{array}$ & $\begin{array}{c}\text { Serial } \\
\text { Dictatorship } \\
\text { (predicted) } \\
(4)\end{array}$ & $\begin{array}{c}\text { Serial } \\
\text { Dictatorship } \\
\text { (predicted) } \\
(5)\end{array}$ \\
\hline Panel A. All & 0.243 & 0.243 & $\begin{array}{c}0.212 \\
{[0.201,0.223]}\end{array}$ & $\begin{array}{c}0.141 \\
{[0.120,0.145]}\end{array}$ & $\begin{array}{c}0.231 \\
{[0.226,0.233]}\end{array}$ \\
\hline \multicolumn{6}{|l|}{ Panel B. Sector } \\
\hline - Manufacturing & 0.197 & 0.197 & $\begin{array}{c}0.197 \\
{[0.193,0.200]}\end{array}$ & $\begin{array}{c}0.173 \\
{[0.163,0.175]}\end{array}$ & $\begin{array}{c}0.185 \\
{[0.181,0.188]}\end{array}$ \\
\hline - Construction & 0.225 & 0.225 & $\begin{array}{c}0.232 \\
{[0.215,0.249]}\end{array}$ & $\begin{array}{c}0.150 \\
{[0.099,0.148]}\end{array}$ & $\begin{array}{c}0.219 \\
{[0.199,0.226]}\end{array}$ \\
\hline - Agriculture & 0.421 & 0.421 & $\begin{array}{c}0.269 \\
{[0.165,0.338]}\end{array}$ & $\begin{array}{c}-0.052 \\
{[-0.168,-0.005]}\end{array}$ & $\begin{array}{c}0.405 \\
{[0.388 .0 .416]}\end{array}$ \\
\hline - Fisheries & 0.574 & 0.574 & $\begin{array}{c}0.293 \\
{[0.170,0.413]}\end{array}$ & $\begin{array}{c}0.041 \\
{[-0.121,0.082]}\end{array}$ & $\begin{array}{c}0.569 \\
{[0.551,0.576]}\end{array}$ \\
\hline \multicolumn{6}{|c|}{ Panel C. Priority Scores } \\
\hline$-\mathrm{NA}$ & 0.245 & 0.248 & $\begin{array}{c}0.214 \\
{[0.202,0.225]}\end{array}$ & $\begin{array}{c}0.140 \\
{[0.118,0.145]}\end{array}$ & $\begin{array}{c}0.238 \\
{[0.233,0.240]}\end{array}$ \\
\hline - Low & 0.132 & 0.174 & $\begin{array}{c}0.192 \\
{[0.185,0.197]}\end{array}$ & $\begin{array}{c}0.170 \\
{[0.157,0.172]}\end{array}$ & $\begin{array}{c}0.169 \\
{[0.164,0.176]}\end{array}$ \\
\hline - Middle & 0.245 & 0.222 & $\begin{array}{c}0.205 \\
{[0.196,0.212]}\end{array}$ & $\begin{array}{c}0.156 \\
{[0.137,0.156]}\end{array}$ & $\begin{array}{c}0.205 \\
{[0.194,0.208]}\end{array}$ \\
\hline - High & 0.372 & 0.326 & $\begin{array}{c}0.230 \\
{[0.196,0.270]}\end{array}$ & $\begin{array}{c}0.080 \\
{[0.028,0.093]}\end{array}$ & $\begin{array}{c}0.305 \\
{[0.286,0.310]}\end{array}$ \\
\hline \multicolumn{6}{|l|}{ Panel D. Year } \\
\hline-2013 & 0.233 & 0.234 & $\begin{array}{c}0.206 \\
{[0.195,0.216]}\end{array}$ & $\begin{array}{c}0.136 \\
{[0.116,0.140]}\end{array}$ & $\begin{array}{c}0.222 \\
{[0.216,0.224]}\end{array}$ \\
\hline-2014 & 0.254 & 0.253 & $\begin{array}{c}0.218 \\
{[0.205,0.229]}\end{array}$ & $\begin{array}{c}0.147 \\
{[0.124,0.151]}\end{array}$ & $\begin{array}{c}0.242 \\
{[0.237,0.244]}\end{array}$ \\
\hline
\end{tabular}

Notes: This table shows the fraction of job postings that lost their workers within a year. The rest of the explanations are found in the note in Table 3. Numbers in brackets show the 95th percent confidence interval based on bootstrapping. See details in the main text.

\footnotetext{
${ }^{9}$ See Articles 8-1, 2, and 4 of "Act on the Guarantee of Workers' Retirement Benefits" (i.e., Geunroja Toejikgubyeo Bojangbup) and Articles 2-1(6) and 2-2 of the "Labor Standard Act" (i.e., Geunrogijunbup).

${ }^{10}$ In Sections 1 and 2 of the Online Appendix, we further examine the economic consequences for workers who are separated from their initial jobs in less than a year. Our results suggest that on average, early job termination may not be beneficial to workers or to firms.
} 
some workers may benefit from terminating their current contracts and working for other firms, resulting in early job separations ex-poste. However, if the current matching process accounts for a sizable portion of early job separation that could have been avoided, then, ex-ante, it would be better to adjust the matching process so that workers and firms do not have to bear the associated opportunity costs.

In our sample, 24 percent of the matches broke down within a year, as shown in column 1 of Table 4. There are considerable variations across sectors. For example, the smallest share of breakdowns (20 percent) was in manufacturing, followed by construction (23 percent), while the agricultural and fisheries sectors showed 42 and 57 percent of separation rates, respectively. Although the EPS favors firms with high priority scores, we find no evidence that those firms have more successful matching outcomes, at least from the summary statistics. On average, the matches with the firms without priority scores have a 24 percent chance of breaking down within a year, whereas the matches with the firms in the highest priority group have a 37 percent chance of breaking down. Finally, the job separation rate may vary by the year when matches were formed. The matches formed in 2013 show a 23 percent chance of breaking down while those formed in 2014 show a 25 percent chance.

\subsection{Predictors of Early Job Separation}

\section{Overview}

This subsection presents empirical models and the estimation results to account for the early job separation rates in our sample. Despite the rich information in our data, we devise rather restrictive empirical specifications based on OLS regressions in order to use the results in predicting job separation rates for the worker-firm pairs that are not matched in our sample. For example, our sample includes multiple job postings from a firm, and thus we can use firm-fixed effects regression models. However, we do not use those models because our ultimate goal is to propose to the Korean government an alternative matching algorithm that generates lower job separation rates so that the government can use it to match firms and workers in the future. Thus, we do not use explanatory variables that are not available for future participants in the EPS. By definition, the fixed effects of a firm can be estimated only if the firm already participated in the EPS, but that information is not available for firms that have not participated in the system yet. Likewise, we do not use the information on firms' priority scores as an explanatory variable because the priority score is a policy variable that is not predetermined but is set each year.

For this reason, we do not interpret our estimation results as causal effects of an explanatory variable on the likelihood of early job separation. However, we still need the estimated correlations between observables and the likelihood of early job 
separation to remain stable in order to reliably predict future outcomes. We examine the reliability of our estimation results by conducting the following out-of-sample check. Specifically, we estimate our model based on the 2013 and 2014 sample and then use the estimation results to predict the likelihood of job separation among job matchings in 2015. If our estimated empirical relationships are stable, then our predicted job separation rates for the 2015 job postings will be close to the actual outcomes, which we find is the case.

\section{Empirical Specifications}

A linear regression model is used to analyze how firm and worker characteristics may account for the likelihood of job separation within a year (Table 5). The explanatory variables include firms' characteristics, workers' characteristics, and the interaction between these two sets of characteristics. As for firms' characteristics, we include dummies indicating the firm's location, wage level, provision of all four types of insurance, preferred sex, and Korean language skill requirement. As for workers, we use age and indicators of nationality, sex, language skills, preferred sector, and location. We also control for indicators that indicate whether the firms' and workers' preferences are respected in the match-whether the current job belongs to the sector or industry in which the worker would like to work, whether the job is located in the worker's preferred location, and whether the worker satisfies the firm's preferences as to nationality, age, and sex. The standard errors are clustered at the level of a labor market defined by month, year, and sector to allow for the possibility that random shocks may jointly affect market participants. We conduct this analysis for all matched jobs (column 1) and by sector (columns 2 through 5).

Note that these control variables are displayed in the search platform that case workers in job centers use to browse candidates. Specifically, although it is possible that firms may have observed more detailed information on job candidates on the short list, most job candidates available to firms have been screened based on these variables. Narrowing down the set of controls can help get a larger number of observations with all the information. Finally, we conduct a robustness check by including more control variables. We find that our results remain qualitatively the same (see Section 6).

As expected, firms providing all four types of insurances have lower job separation rates, and the effects are stronger in the agricultural and fisheries sectors. Job separation rates for firms providing all four types of insurances are 17 and 14 percentage points lower in the fisheries and agricultural sectors, respectively, compared to firms not providing all four types of insurances. Firms in the highest wage category (category 5) generally have lower job separation rates compared with those classified in the lowest wage category, but firms in the middle wage categories 
[Table 5] Likelihood of Quitting Within a Year: Linear Baseline Model

\begin{tabular}{|c|c|c|c|c|c|}
\hline Sectors & All & Manufacturing & Construction & Agriculture & Fisheries \\
\hline $\begin{array}{l}\text { Actual probability of } \\
\text { job separation withina } \\
\text { year }\end{array}$ & 0.243 & 0.197 & 0.225 & 0.421 & 0.574 \\
\hline No. obs. & 73,930 & 57,779 & 4,360 & 7,839 & 3,952 \\
\hline R-squared & $\begin{array}{c}0.122 \\
(1)\end{array}$ & $\begin{array}{c}0.079 \\
(2)\end{array}$ & $\begin{array}{c}0.130 \\
(3)\end{array}$ & $\begin{array}{l}0.072 \\
(4)\end{array}$ & $\begin{array}{c}0.082 \\
(5)\end{array}$ \\
\hline F: Construction & $\begin{array}{c}0.043 * * * \\
(0.007)\end{array}$ & - & - & - & - \\
\hline F: Agriculture & $\begin{array}{c}0.202 * * * \\
(0.007)\end{array}$ & - & - & - & - \\
\hline F: Fisheries & $\begin{array}{c}0.382 * * * \\
(0.009)\end{array}$ & - & - & - & - \\
\hline F: Providing 4 insurances & $\begin{array}{c}-0.020 * * * \\
(0.004)\end{array}$ & $\begin{array}{l}-0.010^{*} \\
(0.005)\end{array}$ & $\begin{array}{c}-0.043 * * * \\
(0.013)\end{array}$ & $\begin{array}{c}-0.141^{* * *} \\
(0.027)\end{array}$ & $\begin{array}{c}-0.169 * * * \\
(0.051)\end{array}$ \\
\hline F: Wage category 2 & $\begin{array}{c}0.005 \\
(0.004)\end{array}$ & $\begin{array}{c}0.006 \\
(0.007)\end{array}$ & $\begin{array}{l}-0.011 \\
(0.017)\end{array}$ & $\begin{array}{l}-0.023 \\
(0.046)\end{array}$ & $\begin{array}{c}0.038 \\
(0.055)\end{array}$ \\
\hline - category 3 & $\begin{array}{c}0.052^{* * *} \\
(0.005)\end{array}$ & $\begin{array}{c}0.045^{* * *} \\
(0.010)\end{array}$ & $\begin{array}{l}0.041^{* *} \\
(0.023)\end{array}$ & $\begin{array}{c}0.025 \\
(0.038)\end{array}$ & $\begin{array}{l}-0.028 \\
(0.030)\end{array}$ \\
\hline - category 4 & $\begin{array}{c}0.059^{* * *} \\
(0.005)\end{array}$ & $\begin{array}{c}0.065^{* * *} \\
(0.013)\end{array}$ & $\begin{array}{c}0.028 \\
(0.027)\end{array}$ & $\begin{array}{c}0.037 \\
(0.038)\end{array}$ & $\begin{array}{c}-0.072^{* *} \\
(0.050)\end{array}$ \\
\hline - category 5 & $\begin{array}{c}-0.021^{* * *} \\
(0.007)\end{array}$ & $\begin{array}{l}-0.011 \\
(0.010)\end{array}$ & $\begin{array}{c}-0.096^{* * *} \\
(0.022)\end{array}$ & $\begin{array}{l}-0.016 \\
(0.039)\end{array}$ & $\begin{array}{c}-0.134 * * \\
(0.064)\end{array}$ \\
\hline $\mathrm{W}$ : age & $\begin{array}{c}-0.003 * * * \\
(0.000)\end{array}$ & $\begin{array}{c}-0.003 * * * \\
(0.001)\end{array}$ & $\begin{array}{l}-0.001 \\
(0.002)\end{array}$ & $\begin{array}{l}-0.000 \\
(0.001)\end{array}$ & $\begin{array}{c}0.002 \\
(0.002)\end{array}$ \\
\hline W: female & $\begin{array}{c}-0.017^{* * *} \\
(0.007)\end{array}$ & $\begin{array}{l}-0.003 \\
(0.010)\end{array}$ & $\begin{array}{l}-0.002 \\
(0.026)\end{array}$ & $\begin{array}{c}0.009 \\
(0.015)\end{array}$ & - \\
\hline W: Korean - Good & $\begin{array}{c}-0.120^{* * *} \\
(0.006)\end{array}$ & $\begin{array}{c}-0.118 * * * \\
(0.028)\end{array}$ & $\begin{array}{c}-0.096 * * * \\
(0.034)\end{array}$ & $\begin{array}{c}-0.114 * * * \\
(0.029)\end{array}$ & $\begin{array}{c}-0.231 \text { *** } \\
(0.059)\end{array}$ \\
\hline - Excellent & $\begin{array}{c}-0.127^{* * *} \\
(0.008)\end{array}$ & $\begin{array}{c}-0.122 * * * \\
(0.033)\end{array}$ & $\begin{array}{c}-0.110^{* * *} \\
(0.039)\end{array}$ & $\begin{array}{c}-0.152^{* * *} \\
(0.041)\end{array}$ & $\begin{array}{c}-0.348 * * * \\
(0.077)\end{array}$ \\
\hline Sector: $\mathrm{W}=\mathrm{F}$ & $\begin{array}{l}-0.000 \\
(0.006)\end{array}$ & $\begin{array}{l}-0.005 \\
(0.008)\end{array}$ & $\begin{array}{c}0.032 \\
(0.024)\end{array}$ & $\begin{array}{c}0.277 * * * \\
(0.035)\end{array}$ & $\begin{array}{c}0.045 \\
(0.068)\end{array}$ \\
\hline Industry: $\mathrm{W}=\mathrm{F}$ & $\begin{array}{c}-0.011^{* * *} \\
(0.004)\end{array}$ & $\begin{array}{l}-0.005 \\
(0.004)\end{array}$ & $\begin{array}{c}-0.040^{* *} \\
(0.019)\end{array}$ & $\begin{array}{c}-0.075^{* * *} \\
(0.013)\end{array}$ & $\begin{array}{l}-0.004 \\
(0.014)\end{array}$ \\
\hline Location: $\mathrm{W}=\mathrm{F}$ & $\begin{array}{c}-0.082^{*} \\
(0.043)\end{array}$ & $\begin{array}{c}-0.084 * * \\
(0.042)\end{array}$ & $\begin{array}{c}-0.244 * * * \\
(0.073)\end{array}$ & $\begin{array}{l}-0.053 \\
(0.160)\end{array}$ & $\begin{array}{c}0.080 \\
(0.128)\end{array}$ \\
\hline Location: $\mathrm{W} \neq \mathrm{F}$ & $\begin{array}{l}-0.014 \\
(0.043)\end{array}$ & $\begin{array}{l}-0.027 \\
(0.042)\end{array}$ & $\begin{array}{c}-0.109^{*} \\
(0.057)\end{array}$ & $\begin{array}{c}0.060 \\
(0.173)\end{array}$ & $\begin{array}{c}0.072 \\
(0.124)\end{array}$ \\
\hline Nationality: W=F's 1st & $\begin{array}{c}0.001 \\
(0.010)\end{array}$ & $\begin{array}{c}0.003 \\
(0.014)\end{array}$ & $\begin{array}{l}-0.048 \\
(0.035)\end{array}$ & $\begin{array}{c}0.002 \\
(0.022)\end{array}$ & $\begin{array}{c}0.006 \\
(0.043)\end{array}$ \\
\hline Nationality: $W=F$ 's 2nd & $\begin{array}{l}-0.010 \\
(0.010)\end{array}$ & $\begin{array}{l}-0.010 \\
(0.015)\end{array}$ & $\begin{array}{l}-0.009 \\
(0.039)\end{array}$ & $\begin{array}{l}-0.030 \\
(0.029)\end{array}$ & $\begin{array}{l}-0.069 \\
(0.045)\end{array}$ \\
\hline Nationality: $\mathrm{W} \neq \mathrm{F}$ & $\begin{array}{c}-0.002 \\
(0.010) \\
\end{array}$ & $\begin{array}{r}-0.000 \\
(0.015) \\
\end{array}$ & $\begin{array}{l}-0.014 \\
(0.050) \\
\end{array}$ & $\begin{array}{l}-0.001 \\
(0.026) \\
\end{array}$ & $\begin{array}{c}0.037 \\
(0.055) \\
\end{array}$ \\
\hline
\end{tabular}

Note: See the note in Table 4. 
[Table 5] Likelihood of Quitting within a Year: Linear Baseline Model (continued)

\begin{tabular}{|c|c|c|c|c|c|}
\hline Sectors & All & Manufacturing & Construction & Agriculture & Fisheries \\
\hline & (1) & (2) & (3) & (4) & (5) \\
\hline \multirow[t]{2}{*}{ W: Bangladesh } & $0.075 * * *$ & $0.061 * * *$ & $0.130 * * *$ & -0.144 & -0.096 \\
\hline & $(0.009)$ & $(0.014)$ & $(0.046)$ & (0.193) & $(0.111)$ \\
\hline \multirow[t]{2}{*}{ W: Myanmar } & $0.037 * * *$ & 0.002 & -0.016 & $0.171^{* * *}$ & - \\
\hline & $(0.007)$ & $(0.013)$ & $(0.018)$ & $(0.024)$ & \\
\hline \multirow[t]{2}{*}{ W: Sri Lanka } & $0.070 * * *$ & $0.063 * * *$ & $0.083^{*}$ & 0.041 & $0.358^{* * *}$ \\
\hline & $(0.007)$ & $(0.010)$ & $(0.046)$ & $(0.125)$ & $(0.087)$ \\
\hline \multirow[t]{2}{*}{ W: China } & $0.082 * * *$ & $0.133 * * *$ & 0.085 & $-0.285 * * *$ & -0.026 \\
\hline & $(0.019)$ & $(0.024)$ & $(0.058)$ & $(0.083)$ & $(0.092)$ \\
\hline \multirow[t]{2}{*}{$\mathrm{W}$ : Indonesia } & -0.009 & $-0.033 * * *$ & -0.027 & $0.372^{*}$ & $0.450 * * *$ \\
\hline & $(0.008)$ & $(0.009)$ & $(0.036)$ & $(0.216)$ & $(0.097)$ \\
\hline \multirow[t]{2}{*}{ W: Kyrgyzstan } & $0.222 * * *$ & $0.221 * * *$ & 0.126 & $-0.763 * * *$ & - \\
\hline & $(0.024)$ & $(0.027)$ & $(0.101)$ & $(0.164)$ & \\
\hline \multirow[t]{2}{*}{ W: Mongolia } & $0.317 * * *$ & $0.304 * * *$ & $0.311 * * *$ & $-0.284 * * *$ & -0.093 \\
\hline & $(0.009)$ & $(0.013)$ & $(0.045)$ & $(0.026)$ & $(0.078)$ \\
\hline \multirow[t]{2}{*}{ W: Nepal } & $0.029 * * *$ & $0.015^{* *}$ & -0.014 & $0.041 * * *$ & -0.061 \\
\hline & $(0.007)$ & $(0.008)$ & $(0.035)$ & $(0.014)$ & $(0.086)$ \\
\hline \multirow[t]{2}{*}{ W: Pakistan } & $0.096^{* * *}$ & $0.084 * * *$ & 0.202 & -0.033 & -0.034 \\
\hline & $(0.012)$ & $(0.013)$ & $(0.126)$ & $(0.204)$ & $(0.114)$ \\
\hline \multirow[t]{2}{*}{ W: Philippines } & -0.004 & $-0.021 * * *$ & $-0.046^{*}$ & $-0.260 * * *$ & - \\
\hline & $(0.007)$ & $(0.009)$ & $(0.031)$ & $(0.037)$ & \\
\hline \multirow[t]{2}{*}{ W: East Timor } & 0.022 & -0.020 & 0.210 & 0.398 & $0.382 * * *$ \\
\hline & $(0.021)$ & $(0.029)$ & $(0.167)$ & $(0.336)$ & $(0.093)$ \\
\hline \multirow[t]{2}{*}{ W: Thailand } & $-0.027 * * *$ & -0.034 & $-0.084 * *$ & $-0.055^{* *}$ & 0.052 \\
\hline & $(0.009)$ & $(0.021)$ & $(0.033)$ & $(0.020)$ & $(0.085)$ \\
\hline \multirow[t]{2}{*}{ W: Uzbekistan } & $0.290 * * *$ & $0.267 * * *$ & $0.359 * * *$ & 0.290 & - \\
\hline & $(0.008)$ & $(0.011)$ & $(0.034)$ & $(0.259)$ & \\
\hline \multirow[t]{2}{*}{ W: Vietnam } & $0.016^{* *}$ & 0.000 & 0.014 & 0.050 & $0.274 * * *$ \\
\hline & $(0.008)$ & $(0.018)$ & $(0.043)$ & $(0.044)$ & $(0.090)$ \\
\hline
\end{tabular}

Notes: The capital letters "F" and "W" stand for firms and workers, respectively. Omitted categories are (1) Manufacturing, (2) not providing all four types of insurance, (3) bottom monthly wage group (category 1), (4) being male, (5) Korean language skill - mediocre (bottom group), (6) worker's preferred sector is the same as the sector in which they were hired, (7) workers have no location preference, and (8) firms have no preference regarding workers' nationality. Cambodia is omitted from the regression. Standard errors are reported in parentheses, clustered at the level of time (month by year) and sector. * significant at 10 percent, ${ }^{* *}$ significant at 5 percent, and ${ }^{* *}$ significant at 1 percent.

(categories 3 and 4) show higher separation rates, with the exception of the fisheries sector. The higher job separation rates in the middle wage categories compared to the bottom category do not necessarily imply a causal effect of wages on job separation rates. For example, consider a firm that has difficulty attracting foreign workers because its work environment is subject to high health risks. Thus, to 
attract workers, the firm may provide wages belonging to middle wage categories, not the bottom category, in line with the labor economic theory of compensating wage differentials. As we have no information on health risks, this correlation between health risks and wages may account for the positive correlation between wages and job separation rates.

With respect to the association between workers' characteristics and job separation rates, the most noteworthy finding is that workers with better Korean language skills are significantly less likely to quit within a year regardless of the sectors of employment. The language premium in maintaining the job seems to be the largest in the fisheries sector. This finding regarding the importance of language skills is worth highlighting because practitioners have questioned the usefulness of the Korean language test as a worker screening tool. Some employers have voiced concerns that even workers with high TOPIK scores are not quite proficient in Korean, and that the TOPIK score has little to do with the competency of a worker. Indeed, the majority of employers do not express a preference regarding language skills and seldom place a weight on language proficiency. Contrary to common perceptions, our analysis shows that having good Korean language skills is strongly associated with low separation rates.

Our estimates show that the rates of job separation are generally lower when the sectoral and industry preferences of the workers are respected, although agriculture deviates from this pattern. Workers who selected agriculture when applying are 28 percentage points more likely to leave their job within a year than workers who selected other sectors but ended up working in agriculture.

Another notable variable is whether workers find a job in their preferred location. For the manufacturing sector, workers who found a job in their preferred location are 8 percentage points less likely to quit than those who did not have any locational preference and 5 percentage points less likely to quit than those whose preference was not respected. These patterns are more significant among workers in construction but not in agriculture and fisheries.

Finally, the job separation rates vary considerably by workers' nationality, although whether employers' preference for workers' nationality is expressed and respected is not a strong predictor for the separation rate. For instance, in manufacturing jobs (column 2), compared with workers from Cambodia (an omitted category), workers from Thailand are 3 percentage points less likely to be separated from their jobs within a year. Workers from Indonesia, Thailand, and the Philippines show lower separation rates than those from Mongolia, Kyrgyzstan, and Uzbekistan. Vietnam is one of the top five countries that send job candidates to Korea, and, in all four sectors, the separation rates among Vietnamese workers are greater than those of workers from other countries. By contrast, workers from Thailand or the Philippines account for less than 10 percent of hired workers but show lower separation rates. This result suggests that workers' networks to their 
compatriots may inadvertently affect the rate of job separation.

\section{Goodness of Fit}

On the basis of this linear regression model, the separation rates are predicted and then compared with the actual data. As shown in columns 1 and 2 in Table 4, our estimated model matches well with the actual data in terms of average (panel A) and each sector (panel B). As for firms' priority groups (panel C), the prediction is comparable, but not as close to the actual as in panels $\mathrm{A}$ and $\mathrm{B}$, because we do not include priority groups as controls in our regression models. The information on priority groups is excluded from our regression because the EPS assigns priority based on firms' performance, making it difficult to consider priority as an exogenous variable. Nonetheless, the difference between the actual and predicted likelihoods is relatively small, ranging from 0 to 4 percentage points. In panel $\mathrm{D}$, we report the predicted separation rates depending on the year. Although we do not control for year fixed effects, the estimation models predict the outcomes well. This finding implies that the increase in separation rates between 2013 and 2014 is due to changes in the composition of observables and not a year-specific effect.

\section{Reliability to Use for the Counterfactual Analysis: Out-of-Sample Check}

We conduct two types of out-of-sample checks. First, we take the empirical estimates based on the 2013 and 2014 sample and predict the outcomes of job matches in 2015 to examine the extent to which our estimates can be informative in predicting outcomes in the future. We take the estimates of our baseline model to predict the separation rates of the job-worker matches formed from January to September 2015. Using this out-of-sample data, we predict the job separation rates under the serial dictatorship assignment mechanism. Columns 4-6 of Table 7 report the results. The average separation rate is 29.5 percent in the data while the prediction is 27.3 percent (columns 4 and 5 of Table 7 , respectively). Although there is a discrepancy between the actual and out-of-sample predictions, the discrepancy (2.1 percentage points) is much smaller than the potential gains from adopting an alternative algorithm, which will be explained in Section 5 .

Second, we randomly select half of our sample from the 2013 and 2014 job postings for estimation and predict the job separation rates for the other half. The one-year job separation rate in the out-of-sample data is 0.241 while the model prediction is 0.244 ; the difference is not statistically significant at the conventional level. 


\section{Counterfactuals}

\subsection{Strategy}

In this section, we examine the extent to which the EPS could improve matching outcomes compared to the status quo by adopting alternative matching methods. Following the market design literature, we consider the random and serial dictatorship assignments. In random assignment, a firm and a worker are randomly assigned to form a match for a given month in a year during our sample period. Meanwhile, serial dictatorship assignment sorts firms by the EPS's priority scores in descending order and assigns them to the best candidates from among those who are available. We examine the serial dictatorship assignment as an alternative algorithm to the status quo for two reasons. First, serial dictatorship assignment is closely related to actual practice, in which EPS sequentially invites firms based on their ranking. The earlier a firm visits the job center, the larger the pool of job candidates the firm may examine. Second, although, in theory, the use of serial dictatorship does not necessarily generate lower job separation rates than the status quo algorithm, our alternative algorithm based on serial dictatorship can reduce the job separation rates in practice. That is because the status quo algorithm allows EPS participants to browse only a small number of available candidates on an ad-hoc basis, possibly generating Pareto inefficiency. By contrast, our alternative algorithm described below examines all available candidates when a firm makes a hiring decision, generating Pareto-efficient matchings.

In our simulation, for a given month and year, we sort job postings in descending order based on their priority categories (high, middle, low, followed by the group of firms without priority scores). Within each category, firms are sorted on the basis of the predicted job separation rates with their current employees in ascending order. Next, we take one firm from the queue in each category at a time, calculate its job separation rates across all available foreign workers, select the worker who yields the lowest job separation rate for that firm, remove that worker from the pool of available workers, and then move to the next firm in the queue. If there are any ties, then one firm or worker will be selected randomly. By placing firms with low job separation rates early in the queue, we favor firms who expect low job separation rates under the status quo and are thus less willing to accept any policy changes.

We present two types of serial dictatorship assignments: one is cross sectoral and the other is within sectoral assignment. For the cross-sectoral matching, for a given month and year, we create a market consisting of all workers and firms, regardless of their sector, location, or industry. Then, based on the priority order, firms are allowed to choose the job candidate who yields the highest success rate (i.e., lowest separation rate). For the within-sectoral matching, we segment the market by sector 
and carry out the assignment within sector.

Finally, we incorporate the estimation and simulation errors by bootstrapping. In particular, 100 sets of estimates are drawn from the linear regression and, for each set, we simulate the outcomes under random assignment and serial dictatorship assignment. We then report the average and the 95th percent confidence interval from the 100 simulations.

\subsection{Results}

The predicted rates of job separation within a year of random matching, crosssectoral serial dictatorship, and within-sectoral serial dictatorship assignment are presented in columns 3 to 5 of Table 4, respectively, in comparison to the actual and predicted outcomes of the status quo (columns 1 and 2 of Table 4, respectively).

In general, the outcomes of the random assignments are not worse, and are often better, than the status quo, implying that the current matching procedure can be improved. The overall predicted separation rate is 21 percent, 3.1 percentage points lower than the status quo, and the difference is statistically different at the 5 percent level. Random matching performs particularly well for the agricultural and fisheries sectors, reducing the separation rates by 15 and 28 percentage points, respectively, or roughly 50 percent. However, the separation rates for the manufacturing and construction sectors remain very close to the status quo. For priority groups, random matching decreases separation rates in all but the lowest-priority group. In particular, the highest-priority group shows the largest drop in separation rates, 9.6 percentage points, suggesting that the status quo does not match the policy intention of the EPS.

The results based on cross-sectoral serial dictatorship (column 4) show significant improvement in the matching outcome compared with the status quo (column 2). The overall separation rate is predicted to be 14.1 percent, 10.2 percentage points lower than the status quo. This difference is statistically significant at the 5 percent level. The improvement is observed in all sectors. That is, the average separation rate in the manufacturing sector decreases from 19.7 percent to 17.3 percent, a total of 2.4 percentage points. For the construction sector, there is a 7.5 percentage point reduction. The agricultural and fisheries sectors show a dramatic reduction in separation rates: over 42 percentage points. Note that we have a negative predicted separation rate for the agricultural sector because a linear regression model is used and the improvement is significant (see further discussions in Section 6). As for the priority groups (panel C), jobs in the highest-priority ("High") group show the largest improvement, a 24.6 percentage point reduction in separation rates. Notably, even for jobs in the lowest-priority ("Low") group, the matching outcome slightly improves.

We find similar results when we apply our serial dictatorship assignment to the 
2015 job postings. The alternative algorithm reduces the early job separation rate from 27.3 percent in our status-quo simulation to 15.6 percent, as shown in columns 5 and 6 of Table 7, respectively. Although a gap appears between the actual and our prediction (i.e., 2.1 percentage points), it is much smaller compared to the potential gains from adopting the alternative algorithm (11.7 percentage points).

By contrast, when our serial dictatorship algorithm is applied separately within a given sector, the predicted job separation rate decreases from 24.3 percent to 23.1 percent (i.e., a decrease of 1.2 percentage points), as seen in column 5 of Table 4.

\subsection{Why is the Matching Outcomes of the Status Quo Poor?}

This subsection examines the reasons behind the poor performance of the status quo relative to serial dictatorship assignment and even random assignment.

\section{Market Segmentation by Sector}

Our earlier findings show that market segmentation by sector plays a key role in explaining the differences between various matching algorithms. To understand the mechanism, we compare sorting patterns between firms and workers across matching algorithms. As shown in Table 3 (columns 1-4), one of the notable differences between the status quo and the alternative algorithms (random matching and serial dictatorship) is the degree of sorting along the preferred sector and the actual sector of assignment. For example, in our dataset, 92 percent of jobs are matched based on workers' sector preferences, while in the cross-sectoral serial dictator assignment, only 62 percent of jobs are matched based on workers' preferences.

The results of within-sector serial dictatorship matching also highlight the extent to which market segmentation by sector matters. Under this serial dictatorship, 95 percent of jobs hired workers based on their sector preferences and 46 percent of jobs respected workers' preferences as to industry (see column 4 of Table 3). These sorting patterns are highly comparable to the actual pattern (column 1) relative to the two alternative assignment methods (columns 2 and 3). In this case, we observe a much smaller improvement in separation rates than under the initial serial dictatorship assignment.

Existing studies report that the costs of a job search across segmented markets may play an important role in determining job outcomes. Thus, an introduction of technologies and policies that lower job-search costs across segmented markets may substantially alter who is matched with whom. For example, Bagues and Labini (2009) report that an Internet job search yields a differential sorting pattern among workers and firms across geographic locations. Lee (2016) likewise finds that online dating platforms weaken occupation and geographical sorting but strengthen 
sorting along the education and demographic characteristics between men and women. Moreover, Niederle and Roth (2003) show that, in the U.S. labor market for gastroenterologists, the centralized search mechanism expands the scope of the market, promoting the geographic mobility of workers. These findings suggest possible benefits from reducing market segmentation, consistent with the results from this study.

Furthermore, recall that our results on the determinants of job separation (Table 5) suggest a large variation in the job separation rate across workers' nationality and sectors. Compared with Cambodia, workers from Mongolia, China, and Kyrgyzstan show higher separation rates in the manufacturing and construction sectors but lower rates in the agricultural sector. Thus, holding other factors constant, it is expected that the job separation rates can decline by allowing the reallocation of a worker from the manufacturing sector to the agricultural sector, for example. Section 3 of the Online Appendix reports the predicted effect of alternative algorithms by workers' characteristics, including nationality, education, and Korean language skills.

This finding that the large gain from the alternative algorithm is driven by market integration across sectors, however, has a significant caveat. In our empirical analysis, we rely on only 8 percent of job matches in which worker's sector preference is not respected to yield the predicted likelihood of job separation within a year under the cross-sectoral scenario. Suppose that, conditional on observables, those 8 percent of workers are more productive than other workers regardless of what sector they work in. If case workers at job centers can identify such unobservable productivity, then they may select these workers for any sector, regardless of the workers' preference. Although we doubt such scenario to be realistic in our setting, we cannot rule out the possibility. Thus, we take our simulation results as suggestive_ — not definitive_-evidence of possible benefits from market integration.

\section{Reliance on Stated Preferences}

As discussed above, the EPS employs matching practices that heavily rely on stated preferences submitted by workers and firms. Contrary to what is commonly believed, matching outcomes can be improved if the stated preferences are not so crucial to job matching. This is because stated preferences may not necessarily reflect the true, underlying preferences of workers and firms, especially when there is limited information on which to base an expectation of how productive a match will turn out to be.

Our results in Table 4 show that, indeed, many control variables constructed based on the stated preferences are statistically insignificant at conventional levels. For example, compared with cases in which firms have no preference regarding 
workers' nationality, there is no statistical difference in matching success if a firm hires a worker whose nationality is the same as the firm's top or second-highest preference (Nationality: W=F's 1st, W=F's 2nd) or hires a worker whose nationality does not match the firm's preferences (Nationality: $\mathrm{W} \neq \mathrm{F}$ ). These findings suggest that Korean firms may not have accurate information when they submit their preferences. Several firms that we interviewed expressed their preference for Nepalese workers because they think the Nepalese are easy to work with. However, as shown in Table 4, there are no advantages to hiring Nepalese workers in terms of separation rates. If anything, the matches with Nepalese are more likely to break within a year compared with those with Cambodians for manufacturing and agricultural sector jobs.

Similarly, we were told by firms that Korean language test scores are not useful in predicting the competency of a worker. Contrary to firms' perceptions, however, having good Korean language skills is associated with low separation rates. In fact, a sizable portion of Korean firms report indifference about various worker characteristics (Section 3.2.2). These patterns jointly suggest that firms in the EPS may not have sufficient information on workers, and thus an algorithm heavily dependent on the stated preferences of firms may generate inefficient matches.

\section{Robustness Checks}

\subsection{Alternative Outcomes}

\section{Separation Initiated by Workers}

Among the matches that broke down within a year, 77 percent (19 percent among all job matchings) are due to the worker's decision (see column 1 of Table 6). While firms' decisions for job separation tend to be due to external factors, such as economic downturns and bankruptcy, workers' decisions for job separation may be more closely related to the quality of job matching. Thus, we investigate the likelihood of job separation initiated by workers. The separation pattern is not qualitatively different when focusing only on worker-initiated job separations; separation rates are the highest in the agricultural and fisheries sectors (panel B), and firms belonging to the highest-priority group ("High") show the highest separation rate (panel C).

The linear regression model is estimated using the worker-initiated job separation rate as a dependent variable. The predicted separation rates are reported in column 2 of Table 6 . Similar to our baseline case, the model fit is close to the actual. We then conduct a cross-sectoral serial dictatorship assignment in a given time and report the predicted separation rates in column 3. Comparable to our 
baseline results, the alternative assignment reduces separation rates by 6.9 percentage points (37 percent), and the reduction is statistically significant at the 5 percent level. Just as in the baseline analysis, the improvement is substantial for the agricultural and fisheries sectors as well as the top priority group of firms ("High").

[Table 6] Alternative Outcomes

\begin{tabular}{|c|c|c|c|c|c|c|}
\hline \multirow{2}{*}{$\begin{array}{l}\text { Types } \\
\begin{array}{l}\text { Matching } \\
\text { (source) }\end{array}\end{array}$} & \multicolumn{3}{|c|}{$\begin{array}{l}1 \text { if the worker broke the labor } \\
\text { contract in less than one year } \\
\text { (initiated by worker) }\end{array}$} & \multicolumn{3}{|c|}{$\begin{array}{c}1 \text { if the labor contract was } \\
\text { broken down in less than } \\
\text { two years }\end{array}$} \\
\hline & $\begin{array}{c}\text { Status } \\
\text { quo } \\
\text { (actual) } \\
(1) \\
\end{array}$ & $\begin{array}{c}\text { Linear } \\
\text { regression } \\
\text { (predicted) } \\
(2) \\
\end{array}$ & $\begin{array}{l}\text { Cross-sector } \\
\text { serial } \\
\text { dictatorship } \\
\text { (predicted) } \\
\text { (3) }\end{array}$ & $\begin{array}{c}\text { Status } \\
\text { quo } \\
(\text { actual) } \\
(4) \\
\end{array}$ & $\begin{array}{c}\text { Linear } \\
\text { regression } \\
\text { (predicted) } \\
(5)\end{array}$ & $\begin{array}{c}\text { Cross-sector } \\
\text { serial } \\
\text { dictatorship } \\
\text { (predicted) } \\
(6)\end{array}$ \\
\hline Panel A. All & 0.188 & 0.188 & $\begin{array}{c}0.119 \\
{[0.100,0.123]}\end{array}$ & 0.446 & 0.446 & $\begin{array}{c}0.330 \\
{[0.298,0.334]}\end{array}$ \\
\hline \multicolumn{7}{|l|}{ Panel B. Sector } \\
\hline -Manufacturing & 0.166 & 0.166 & $\begin{array}{c}0.144 \\
{[0.137,0.148]}\end{array}$ & 0.398 & 0.398 & $\begin{array}{c}0.374 \\
{[0.355,0.377]}\end{array}$ \\
\hline -Construction & 0.190 & 0.190 & $\begin{array}{c}0.120 \\
{[0.088,0.122]}\end{array}$ & 0.452 & 0.452 & $\begin{array}{c}0.318 \\
{[0.241,0.319]}\end{array}$ \\
\hline -Agriculture & 0.320 & 0.319 & $\begin{array}{c}-0.024 \\
{[-0.145,0.031]}\end{array}$ & 0.634 & 0.634 & $\begin{array}{c}0.140 \\
{[-0.019,0.229]}\end{array}$ \\
\hline -Fisheries & 0.303 & 0.303 & $\begin{array}{c}0.041 \\
{[-0.123,0.086]}\end{array}$ & 0.733 & 0.733 & $\begin{array}{c}0.078 \\
{[-0.087,0.165]}\end{array}$ \\
\hline \multicolumn{7}{|c|}{ Panel C. Priority Scores } \\
\hline$-\mathrm{NA}$ & 0.188 & 0.192 & $\begin{array}{c}0.119 \\
{[0.099,0.122]}\end{array}$ & 0.446 & 0.449 & $\begin{array}{c}0.329 \\
{[0.296,0.334]}\end{array}$ \\
\hline -Low & 0.109 & 0.143 & $\begin{array}{c}0.138 \\
{[0.128,0.146]}\end{array}$ & 0.311 & 0.371 & $\begin{array}{c}0.372 \\
{[0.351,0.378]}\end{array}$ \\
\hline -Middle & 0.204 & 0.182 & $\begin{array}{c}0.128 \\
{[0.114,0.133]}\end{array}$ & 0.476 & 0.438 & $\begin{array}{c}0.352 \\
{[0.326,0.356]}\end{array}$ \\
\hline -High & 0.276 & 0.230 & $\begin{array}{c}0.074 \\
{[0.019,0.085]}\end{array}$ & 0.584 & 0.531 & $\begin{array}{c}0.241 \\
{[0.171,0.258]}\end{array}$ \\
\hline \multicolumn{7}{|l|}{ Panel D. Year } \\
\hline-2013 & 0.173 & 0.175 & $\begin{array}{c}0.109 \\
{[0.092,0.114]}\end{array}$ & 0.409 & 0.419 & $\begin{array}{c}0.310 \\
{[0.279,0.313]}\end{array}$ \\
\hline-2014 & 0.205 & 0.202 & $\begin{array}{c}0.131 \\
{[0.111,0.133]} \\
\end{array}$ & 0.493 & 0.481 & $\begin{array}{c}0.353 \\
{[0.321,0.359]}\end{array}$ \\
\hline
\end{tabular}

Notes: Columns 1-3 show the fraction of contracts that workers broke in less than a year initiated by the worker. Columns $4-6$ show the fraction of job postings that lost their workers in less than two years. The rest of the explanations are found in the note in Table 3. Numbers in brackets show the 95 th percent confidence interval based on bootstrapping. See details in the main text. 


\section{Separation Within Two Years}

This subsection examines the likelihood that a job-worker match may break down within two years instead of one year. Given that the latest information we obtained from the EPS was for September 2016, when we analyze matching success based on two-year criteria, the matches made in October-December 2014 are omitted.

In our dataset, 45 percent of jobs broke down within two years (column 4 of Table 6). Given that most workers enter Korea with the initial two-year contract, it is quite striking that almost 45 percent of workers leave their initial workplace without fulfilling the initial contract. We carry out similar analyses based on the regression models and use them to simulate the cross-sectoral serial dictatorship assignment. As shown in column 5, the model fit is good. Column 6 reports the predicted separation rate. The serial dictatorship assignment reduces the two-year separation rate by 12 percentage points ( 27 percent). Consistent with our baseline result, the benefits are considerable for the agricultural and fisheries sectors and the firms that belong to the top priority group (column 5 of Table 3).

\subsection{Regression Models}

\section{Nonlinearity}

We examine the possibility that a nonlinear regression model may outperform our linear model in predicting the success rate in our sample. We use a probit model to predict the likelihood of a job match breaking down within a year. Using the estimates, we report the predicted separation rates in column 2 of Table 7. The results are virtually the same as those from our baseline (column 1 of Table 7), suggesting that the linearity assumption may not critically affect our simulation results.

\section{Extended Controls}

Our dataset includes other observable variables in addition to those used earlier. Examples include workers' education and the number of Korean workers and foreign guest workers a firm has already hired. Our baseline analysis omitted these variables because they were not displayed in job centers' search systems when case workers prepared short lists for firm representatives. In this subsection, we include these omitted variables in our linear regression and estimate the model (see detailed estimates in the Online Appendix, Table A5). This alternative model fits the data better than our baseline in terms of priority scores (panel C, column 3 of Table 7), but the difference in other dimensions (panels $\mathrm{B}$ and $\mathrm{D}$ ) is negligible. 
[Table 7] Robustness Check

\begin{tabular}{lcccccc}
\hline & $\begin{array}{c}\text { Baseline } \\
\text { (OLS) }\end{array}$ & Probit & $\begin{array}{c}\text { Extended } \\
\text { controls }\end{array}$ & \multicolumn{2}{c}{ Out-of-sample } \\
\hline $\begin{array}{c}\text { Matching } \\
\text { (source of } \\
\text { outcomes) }\end{array}$ & $\begin{array}{c}\text { Status } \\
\text { quo } \\
\text { (predicted) }\end{array}$ & $\begin{array}{c}\text { Status } \\
\text { quo } \\
\text { (predicted) }\end{array}$ & $\begin{array}{c}\text { Status } \\
\text { quo } \\
\text { (predicted) }\end{array}$ & $\begin{array}{c}\text { Status } \\
\text { quo } \\
\text { (data) }\end{array}$ & $\begin{array}{c}\text { Status } \\
\text { quo } \\
\text { (predicted) }\end{array}$ & $\begin{array}{c}\text { Cross } \\
\text { sectoral } \\
\text { serial } \\
\text { dictatorship } \\
\text { (predicted) }\end{array}$ \\
\hline Panel A. All & $(1)$ & $(2)$ & $(3)$ & $(4)$ & $(5)$ & $(6)$ \\
Panel B. Sector & 0.243 & 0.243 & 0.243 & 0.295 & 0.273 & 0.156 \\
-Manufacturing & 0.197 & 0.197 & 0.197 & 0.237 & 0.225 & 0.200 \\
-Construction & 0.225 & 0.225 & 0.225 & 0.227 & 0.249 & 0.203 \\
-Agriculture & 0.421 & 0.424 & 0.421 & 0.419 & 0.387 & -0.032 \\
-Fisheries & 0.574 & 0.575 & 0.574 & 0.638 & 0.516 & 0.008 \\
Panel C. Priority Scores & & & & & & \\
-NA & 0.248 & 0.248 & 0.249 & 0.287 & 0.272 & 0.167 \\
-Low & 0.174 & 0.175 & 0.141 & 0.223 & 0.212 & 0.180 \\
-Middle & 0.222 & 0.222 & 0.235 & 0.267 & 0.247 & 0.148 \\
-High & 0.326 & 0.326 & 0.342 & 0.486 & 0.378 & 0.023 \\
Panel D. Year & & & & & & - \\
-2013 & 0.234 & 0.235 & 0.233 & - & - & - \\
-2014 & 0.253 & 0.253 & 0.253 & - & - & - \\
\hline
\end{tabular}

Notes: This table shows the fraction of job postings that lost their workers within a year. The rest of the explanations can be found in the note to Table 3.

\section{Conclusions}

This research examines the determinants of job separation and the extent to which an alternative matching method drawn from market design research can improve worker-firm matching in the context of the Korean market for temporary foreign workers. The current Korean system for temporary labor migration, EPS, features transparent practices and relatively low search costs for both firms and workers. Despite its many advantages, the system can be improved in terms of fostering job matches that are likely to last. Using comprehensive, detailed administrative datasets, we first estimate the quality of the matches made and then simulate the possible outcomes under a serial dictatorship algorithm. Our results indicate that job separation rates can be significantly reduced by relaxing the market segmentation currently imposed by the sector of employment. Additionally, job matching based not entirely on workers' and firms' stated preferences but on revealed patterns of job matching and separation found in historical data can improve the job matching outcomes. 
Our findings raise a few questions for future research. One is to what extent the adoption of an alternative matching algorithm yields positive effects in practice. Despite the substantial gains shown in our simulation results, the actual adoption of the cross-sectoral serial dictatorship assignment may not yield desired outcomes owing to changing expectations or reservation wages. For instance, the workers who initially chose agriculture with a relatively low reservation wage may raise their expectations and reservation wage if assigned to manufacturing. Such a possible difference between the counterfactual and actual experimental outcomes is not unprecedented. For example, based on historical data from the United States Air Force Academy, Carrell, Sacerdote, and West (2013) devise an alternative system for student assignment to maximize academic performance. However, when the system was implemented, they find that the expected benefit did not occur because students altered their peer groups in response to the change. We leave the project of experimenting with the alternative algorithm for future research.

Another research question is to what extent the quality of initial job matches has a prolonged effect on migrant workers. A growing number of studies have documented that the quality of jobs at the beginning of a person's career has lasting effects on the labor market outcomes of that person. For example, Kahn (2010) and Heisz, Oreopoulos, and von Watcher (2012) report that college graduates who started their careers during a recession start with lower-paying jobs than do their counterparts, and this disadvantage is observed even 10 years after college graduation. It would be worth empirically examining whether the initial quality of a job match also has prolonged effects on the job performance of migrant workers during their entire stay in Korea. If so, then a matching mechanism that generates better matches among migrants and firms could have larger benefits than anticipated.

Finally, it would be worth studying the extent to which the lessons from temporary migrant labor markets are applicable to helping long-term immigrants utilize their talents in host countries. Various studies (e.g., Borjas, 2015) report a sizable gap between the labor market outcomes of immigrants and natives. If immigrants face greater difficulty in identifying possible jobs than do natives, for example, due to limited networks and information, then designing a policy that improves the efficiency of their job matches could help reduce this gap. Additional empirical examination is needed to evaluate such a possibility, especially because temporary work can itself affect various economic outcomes of immigrants (see Dustmann and Görlach, 2016, for a review of the literature). 


\section{References}

Agarwal, Nikhil (2015), “An Empirical Model of the Medical Match,” American Economic Review, 105(7), 1939-1978.

Antman, Francisca M. (2012), "Elderly Care and Intrafamily Resource Allocation when Children Migrate," Journal of Human Resources, 47 (2), 331-363.

Bagues, Manuel F., and Mauro Sylos Labini (2009), "Do Online Labor Market Intermediaries Matter? The Impact of Alma Laurea on the University-to-Work Transition," In Studies of Labor Market Intermediation, edited by David H. Autor, 127154. Chicago, IL: University of Chicago Press.

Bansak, Kirk, Jeremy Ferwerda, Jens Hainmueller, Andrea Dillon, Dominik Hangartner, Duncan Lawrence, and Jeremy Weinstein (2018), "Improving Refugee Integration through Data-Driven Algorithmic Assignment," Science, 359(6373), 325-329.

Borjas, George J. (2014), Immigration Economics, Cambridge, MA and London, England: Harvard University Press, ISBN-13: 978-0674049772.

Borjas, George J. (2015), “The Slowdown in the Economic Assimilation of Immigrants: Aging and Cohort Effects Revisited Again," Journal of Human Capital, 9(4), 483-517.

Bureau of Labor Statistics (2018), "Labor Force Characteristics of Foreign-Born Workers Summary,” Economic News Release, May 17. USDL-18-0786.

https://www.bls.gov/news.release/forbrn.nr0.htm/Labor-Force-Characteristics-ofForeign-Born-Workers-Summary.

Card, David, and Giovanni Peri (2016), "Immigration Economics by George Borjas: A Review," Journal of Economic Literature, 54(4), 1333-1349.

Carrell, Scott E., Bruce I. Sacerdote, and James West (2013), "From Natural Variation to Optimal Policy? The Importance of Endogenous Peer Group Formation," Econometrica, 81(3), 855-882.

Cho, Yoonyoung, Anastasiya Denisova, Soonhwa Yi, and Upasana Khadka (2018), Bilateral Arrangement of Temporary Labor Migration: Lessons from Korea's Employment Permit System, Washington, DC: World Bank Group.

Clemens, Michael and David McKenzie (2018), "Why Don't Remittances Appear to Affect Growth?" Economic Journal, 128(612), F179-F209.

Clemens, Michael and Erwin Tiongson (2017), "Split Decisions: Household Finance When a Policy Discontinuity Allocates Overseas Work," Review of Economics and Statistics, 99(3), 531-543.

Coles, Peter, John Cawley, Phillip B. Levine, Muriel Niederle, Alvin E. Roth, and John J. Siegfried (2010), "The Job Market for New Economists: A Market Design Perspective," Journal of Economic Perspectives, 24(4), 187-206.

Cortés, Patricia, and Jessica Pan (2015), "Immigration and Occupational Choice: The Case of Nurses in the United States," CESifo Economic Studies, 61(3-4), 797-823.

Cortés, Patricia, and José Tessada (2011), "Low-Skilled Immigration and the Labor Supply of Highly Skilled Women," American Economic Journal: Applied Economics, 3(3), 88123.

Docquier, Frédéric, and Hillel Rapoport (2012), "Globalization, Brain Drain and 
Development," Journal of Economic Literature, 50(3), 681-730.

Dustmann, Christian, and Joseph-Simon Görlach (2016), "The Economics of Temporary Migrations," Journal of Economic Literature, 54(1), 98-136.

Heisz, Andrew, Philip Oreopoulos, and Till von Watcher (2012), "The Short- and LongTerm Career Effects of Graduating in a Recession," American Economic Journal: Applied Economics, 4(1), 1-29.

International Labour Organization (2017), Global Estimates on International Migrant Workers -- Results and Methodology.

Jones, Will, and Alexander Teytelboym, Forthcoming, “The Local Refugee Match: Aligning Refugees' Preferences with the Capacities and Priorities of Localities," Journal of Refugee Studies, 31(2), 152-178.

Kahn, Lisa B. (2010), "The Long-Term Labor Market Consequences of Graduating from College in a Bad Economy," Labour Economics, 17(2), 303-316.

Kominers, Scott D., Alexander Teytelboym, and Vincent P. Crawford (2017), “An Invitation to Market Design," Oxford Review of Economic Policy, 33(4), 541-571.

Lafortune, Jeanne, José Tessada, and Carolina Conzales-Velosa (2015), "More Hands, More Power? The Impact of Immigration on Farming and Technology Choices in US Agriculture in Early 20th Century," Journal of International Economics, 97(2), 339-358.

Lee, Soohyung (2016), "Effect of Online Dating on Assortative Mating: Evidence from South Korea," Journal of Applied Econometrics, 31 (6), 1120-1139.

Moraga, Jesús Fernández-Huertas, and Hillel Rapoport (2014), "Tradable Immigration Quotas," Journal of Public Economics, 115(July), 94-108.

National Archives of Korea (2006), "Employment Permit System for Temporary Foreign Workers." http://www.archives.go.kr/next/search/listSubjectDescription.do?id=000275\&pageFlag.

Niederle, Muriel, and Alvin E. Roth (2003), "Unraveling Reduces Mobility in a Labor Market: Gastroenterology with and without a Centralized Match," Journal of Political Economy, 111(6), 1342-1352.

Niederle, Muriel, Deborah D. Proctor, and Alvin E. Roth (2006), "What Will Be Needed for the New Gastroenterology Fellowship Match to Succeed?" Gastroenterology, 130(1), 218-224.

Ottaviano, Gianmarco I. P., Giovanni Peri, and Greg C. Wright (2018), "Immigration, Trade and Productivity in Services: Evidence from U.K. Firms," Journal of International Economics, 112(May), 88-108.

World Bank (2016), Migration and Remittances Factbook 2016: Third Edition. Washington, DC: World Bank Group.

https://siteresources.worldbank.org/INTPROSPECTS/Resources/334934-1199807908806/ 4549025-1450455807487/Factbookpart1.pdf. 


\section{구인-구직 매칭의 효율화 방안: 한국의 외국인근로자 제도에의 적용*}

이 수 형** · 조 윤 영***

\section{논문초록}

본 논문은 취업알선방법이 근로자의 조기퇴사율에 얼마만큼 영향을 미치는지 통계학적 기법을 이용하여 분석한다. 이를 위하여 본 연구진 은 한국의 외국인노동자 도입 제도에 관련한 전수 행정 통계 자료를 분석하였다. 그 이유는, 일반적인 일자리와는 달리, 외국인노동자 도입 제도의 경우 한국정부가 외국인 선발과 한국 기업간의 알선 과정을 감독하기 때문에 관련된 자세한 통계 정보가 수집되어 있어, 엄밀한 연구가 가능하였기 때문이다. 본 연구진은 현재의 외국인 근로자와 한 국 기업을 매칭하는 방식이 개선의 여지가 있음을 보였다. 또한, 본 연구진이 제안하는 대안적인 알고리즘을 사용할 경우 1 년미만의 조기 퇴사율을 약 $45 \%$ 감소시키는 것을 발견하였다. 외국근로자들의 조기 퇴사는 한국기업과 행정업무 차원에서 상당한 부담을 초래하며, 외국 인들의 입장에서도 실직의 위험에 노출되는 등 위험 요소로 볼 수 있 다. 이를 감안할 때 본 연구진이 제안하는 대안적인 알고리즘을 시험 적으로 도입해볼 현실적 의의가 있다고 판단된다.

핵심 주제어: 일자리 매칭, 외국본 인노동자, 이민, 시장설계 경제학문헌목록 주제분류: $\mathrm{J4}, \mathrm{J} 6, \mathrm{O} 15$

투고 일자: 2020. 6. 18. 심사 및 수정 일자: 2021. 2. 6. 게재 확정 일자: 2021. 4. 30.

* 본 연구는 "Korea-World Bank Partnership Facility"와 KDI School로부터 리서치 펀딩 지원하에 수행되었고, 이수형 교수가 2019년 상반기 IADB 방문시 연구의 일부를 수행하였다. 본 연구진은 임슬기 박사와 Michell Dong의 연구보조, IADB와 AASLE의 세미나 참석자들이 주신 커멘트에 감사드린다. 본 연구물은 세계은행이나 한국정부 등 관련 기관의 공식적인 입장 이 아님을 밝힌다.

** 교신저자, 서울대학교 국제대학원 교수, e-mail: soohlee@snu.ac.kr **** 제1저자, 세계은행 박사, e-mail: ycho1@worldbank.org 